\title{
ELECTORAL SYSTEMS AND THE AUTOCRAT'S TRADE-OFF: EVIDENCE FROM THE RUSSIAN DUMA
}

\author{
Anders Woller ${ }^{1}$
}

\author{
Working paper (June 2021)
}

Legislative elections sustain authoritarian regimes. However, properties of any electoral system may simultaneously benefit and hurt regimes' political prospects. We propose a trade-off between electoral systems facilitating parliamentary bargaining and electoral systems maintaining legislative control. While an electoral system can achieve either, it cannot solve both. We investigate this theory by studying Russian federal deputies, half of which are elected in a first-past-the-post single-member district, the other half on a nationwide closed-party list. Candidates can register on both lists, and district results determine final list affiliation. We exploit that electoral incentives change abruptly for deputies barely winning/losing the district, to identify effects of list affiliation on pro and anti-regime parliamentary behavior. Results support a trade-off: while district deputies bargain more for local amendments in parliamentary speeches, they also more often seek to obstruct legislation. How autocrats weigh this trade-off determines the electoral system, and illuminates electoral system reform in autocracies.

\section{Word count: 11,894}

\footnotetext{
${ }^{1}$ Postdoctoral fellow, Department of Political Science, University of Copenhagen. Address: Øster Farimagsgade 5, DK-1353 København K. Phone: (+45) 35335748. E-mail: woller.awn@gmail.com. I would like to thank Jacob Gerner Hariri, Horacio Larreguy, David Szakonyi, Jessica Gottlieb, Thad Dunning, Anne Rasmussen, Asmus Leth Olsen, Martin Vinæs Larsen, Kristen Kao, Frederik Hjorth, Suthan Krishnarajan, Matilde Tofte Thorsen as well as participants at UC Berkeley's Center on the Politics of Development Working Group Meeting, Gothenburg University's Quality of Government Speaker Series, and Harvard University's Political Economy Workshop for invaluable feedback. Victoria Antonova provided excellent research assistance. All errors are my own.
} 


\section{Introduction}

Though neither free nor fair, elections are widespread across the world's non-democratic regimes. After waves of regime collapses, most recently in the 1980s and 1990s, electoral autocracies now account for $87 \%$ of all authoritarian regimes, making it by far the most predominant type around. ${ }^{2}$ The proliferation of elections naturally fosters an interest in how votes translate into mandates (Gandhi and Heller 2018), and since 1980, $27 \%$ of all authoritarian regimes have modified their electoral system. Consequently, a multitude of electoral systems are present in today's autocracies, with five distinct types each accounting for $10 \%$ of countries or more. ${ }^{3}$ Although the literature presumes such changes reflect institutional manipulation (e.g. Diaz-Cayeros and Magaloni 2001; Gandhi et al. 2019; Lust-Okar and Jamal 2002), the active reconfiguration poses the question what particular benefits and costs accrue to the autocrat from specific electoral systems?

This paper builds a theory in which autocrats have to trade-off properties of particular electoral systems. In doing so, we advance our understanding of the preferences autocrats hold over specific electoral systems, which in turn provides a framework to understand electoral system reform in autocracies. Specifically, the paper investigates how different pro and anti-regime parliamentary behaviors result from being elected locally with less regime control, or nationally with overwhelming regime control. On the one hand, core theories posit that legislative elections in autocracies facilitate co-optation (Gandhi 2008; Malesky and Schuler 2011). By delegating competency over selection of parliamentarians to local elites, the regime obtains information on local elite preferences, which shapes parliament as a forum for bargaining over resources (Gandhi and Przeworski 2007; Malesky

\footnotetext{
${ }^{2}$ See the Varieties of Democracy dataset, 'Legislative electoral regime index' (id: v2xlg_elecreg).

${ }^{3} 29$ countries changed the electoral system out of 108 countries coded as authoritarian at one point throughout the period (Coppedge et al. 2020). For the distribution of electoral systems across autocracies, see Figure A.1.
} 
and Schuler 2010). Investing local elites in the continuation of the regime's rule strengthens the regime and prolongs its time at the pinnacle of power. On the other hand, if such co-optation were to present the opposition with a credible commitment of influence, it will have to weaken the autocrat's control over parliamentarians. Consequently, co-optation carries a cost, as the regime can hardly sanction locally elected deputies who obstruct the legislative process in order to pursue the interests of their local patron (Gandhi et al. 2019). The regime therefore loses the ability to use parliament simply as a rubber stamp of its desired policies. Herein lies the fundamental trade-off: locally elected parliamentarians facilitates parliamentary bargaining with local elites, but weakens the autocrat's legislative control.

We examine the theoretical trade-off in Russia. Russia has held regular, multiparty parliamentary elections throughout the post-soviet period. Still, elections are characterized by the prevalence of clientelism (Frye et al. 2014; 2019), intimidation (Frye et al. 2018), and fraud (Enikolopov et al. 2013). Russia is therefore often used as an example of an electoral authoritarian regime (Levitsky and Way 2002). ${ }^{4}$ The Russian regime has changed its electoral system twice: first in 2007 to a pure proportional system and back again to a mixed member system prior to the 2016 elections. The reforms have raised concerns that the modifications strengthen incumbents' political power (Golosov 2017). Russia is the ideal case to study the trade-offs introduced by distinct electoral incentives. Russia has a mixed-member electoral system in place in which 225 deputies are directly elected in a first-past-the-post single-member district (district deputies) and 225 on a federal proportional representation (PR) closed-party list (party list deputies).

\footnotetext{
${ }^{4}$ Though this is true for the whole period under investigation, Russia did experience democratic backsliding from the mid- to late 1990s. However, even before the backsliding, Russia was grouped with countries generally believed to be non-democracies at the time, including Mexico, Belarus, Tanzania, and the Republic of the Congo (Coppedge et al. 2020).
} 
The electoral system provides deputies with stark differences in constituency type and, consequently, electoral incentives.

Identifying the trade-off causally is challenging. As the theory demonstrates, we have reason to believe institutions are inherently endogenous (Golosov 2017) and to obtain variation in institutions, studies come to rely on cross-country comparisons (Boix and Svolik 2013; Gandhi 2008). We exploit that Russian candidates are allowed to register and campaign on both lists simultaneously ("dual included candidates"), with the final seat determined by the district result. We identify dual included candidates among all 40,000 candidates registered to compete for a State Duma seat since 1993, and employ a regression-discontinuity design exploiting that for district margins of victory close to zero, the type of constituency changes discontinuously. Whereas dual included candidates who barely win the district are elected by a small, geographically concentrated constituency, dual included candidates who barely lose the district - but still gain a seat in the Duma - will have been elected by a nationwide, and geographically dispersed, constituency.

We construct two original datasets to gauge the trade-off. To measure parliamentary bargaining, we merge all parliamentary speeches from 1993 to 2019 (totaling 145,000 speeches) with list affiliation for each deputy in the State Duma. Speeches not only provide an opportunity for the regime to learn about local interests: they also present deputies with a means to influence legislation. Even though lawmaking in the State Duma is controlled by the regime (Noble and Schulman 2018; Remington 2014) and party elites (Remington 2008a), deputies influence distributive politics through suggesting amendments (Krol 2017; Noble 2017). We employ a dictionary method to identify amendments favoring the deputy's local district (from hereon "local amendments"). For robustness, we train a supervised classifier on 4,000 hand-coded speeches. Second, to measure the ex- 
tent to which parliament rubber stamps legislation from the executive, we investigate the extent to which deputies work to obstruct law proposals pre-cleared by the regime. We refer to this as the regime's legislative control. Specifically, we make use of the population of roll-call votes in the Russian Duma which is available from 2000 onward, summing up to just short of 14,000 parliamentary votes.

Results support the trade-off: through shaping the incentives of parliamentarians, electoral systems can either facilitate parliamentary bargaining or sustain legislative control, but hardly both at once. With respect to parliamentary bargaining, deputies barely elected in a single-member district are twice as likely to suggest amendments favoring their region, compared to deputies barely elected on the federal list. However, with respect to legislative control, district deputies are 10 to 20 percent more likely to oppose the regime in parliament by working to obstruct law proposals. When choosing an electoral system, the regime must then trade off parliamentary bargaining for legislative control.

Moreover, the trade-off appears non-trivial to modify. In an effort to weaken regional elites and strengthen legislative control, the Russian regime abandoned both direct gubernatorial elections, as well as the single-member districts which were replaced with a pure-proportional representation system in effect from the 2007-elections (Golosov 2017). Subsequently, the mixed-member electoral system was re-introduced again for the September 2016 elections. Results suggest that the institutional engineering did affect parliamentary behavior. After the reintroduction of the single-member districts in 2016, the Russian regime enjoys significantly more legislative control: district deputies are now 10-15 percent less likely to obstruct legislation, compared to deputies barely elected on the federal list. However, the increased legislative control has been bought with the extent to which local representation facilitates parliamentary bargain: the effect of district 
list affiliation on suggesting local amendments has thus dropped with a factor of ten. The results suggest that even when autocrats have the sufficient parliamentary power to have a choice over electoral systems, it may be a sub-optimal one at best (Gandhi and Heller 2018).

The paper makes several contributions to the literature on nominally democratic institutions in electoral autocracies. By showing how electoral incentives matter for the extent to which deputies represent local districts, the results broaden our understanding of elections generally (Gandhi 2008) as well as how particular candidate selection procedures determine parliamentary responsiveness (Malesky and Schuler 2010). Simultaneously, we push the literature to consider not only benefits accruing to authoritarian regimes from holding elections, but also possible costs with respect to loss of control over parliament. The study furthermore speaks to the trade-offs related to co-option of elites and masses (Magaloni 2008; Svolik 2013) by suggesting that also the design of electoral institutions introduces trade-offs. Most directly, it relates to findings that the first-past-the-post system in autocracies may yield a seat bonus, but simultaneously provide the opposition with incentives to coordinate (Higashijima and Chang 2016, see also Lust-Okar 2004) or weaken the loyalty of power-sharing elites, the "loyalty-performance" trade-off (Gandhi et al. 2019).

Finally, results nuance the literature on political accountability by suggesting that authoritarian elections do in fact discipline politicians. By doing so, the paper adds to the literature on agent shirking in autocracies. Just like their democratic counterparts, office appointments in autocracies revolve around the challenge of delegating competencies to agents with diverging interests (Reuter and Robertson 2012). As ruling elites rely on parliamentarians to convey information on citizen grievances (Truex 2016), regimes face a 
similar problem in terms of monitoring the effort of parliamentarians. This paper suggests that elections could be one means for autocrats to nurture legislative effort, by allowing local constituencies to monitor and possibly sanction politician performance. However, the paper also shows that optimizing electoral institutions is challenging.

\section{Parliamentary co-optation}

For long, authoritarian parliaments were believed to simply rubber stamp legislation coming from the executive, but recent research suggests that they play a more active role. Specifically, parliaments provide an important channel through which regimes obtain information on the preferences of outside elites (Malesky and Schuler 2011; Truex 2016). Seminal contributions have identified how members of authoritarian parliaments facilitate bargaining over policy between the regime and outside interests (Blaydes 2010; Distelhorst and Hou 2017; Gandhi and Przeworski 2007). One way to keep opposition actors content is by allowing representatives to present their interests and exert some influence over policy in parliament (Gandhi 2008). Such parliamentary bargaining is exemplified by delegates in the Chinese National People's Congress - elected by provincial assemblies - who successfully seek out district rewards in the bargaining with the regime (Truex 2016). Also delegates in the Vietnamese National Assembly are responsive to the needs of local constituents, particularly so when delegates are nominated by provincial electoral commissions and not central authorities (Malesky and Schuler 2010, 2011). Others have pointed out how the election or appointment of business people into parliament seems to favor a different type of constituency: industry actors (Szakonyi 2018). These are not idiosyncratic cases, and co-optation through parliamentary bargaining has been found to prolong the rule of authoritarian leaders globally (Gandhi 2008). 


\subsection{Authoritarian elections}

Importantly, the specific procedures for selecting members of parliament determines what interests are being presented to the regime. A growing literature thus suggests that not only parliaments but also elections can prolong authoritarian regimes' time at the pinnacle of power (Boix and Svolik 2013; Gandhi 2008). Though parliamentarians can be appointed, elections provide regimes with an efficient channel to (1) learn about the (electoral) capacity of outside elites and (2) exclusively permit the strongest outside elites to take part in the parliamentary bargaining (Gandhi and Lust-Okar 2009; Gandhi and Przeworski 2007). When regimes loosen control over the parliamentary selection process, elections present a mechanism to include certain outside elites with no requirements pertaining to the regime's information about the distribution of power in society (Malesky and Schuler 2011).

What unifies explanations stressing the effects of elections, is that for the dynamic to play out elections need a certain degree of disciplining power over parliamentarians. If the particular electoral system in place does not determine whom deputies are accountable to, unlike in democracies (Fearon 1999), the ability of elections to co-opt the strongest outside elites vanish. To date we have micro-level evidence of parliamentary behavior in appointed parliaments (Malesky and Schuler 2010; Truex 2016) or studied business candidates, where elections only decide between candidates with predefined constituencies (Szakonyi 2018). However, we lack evidence of how and to what extent electoral incentives affect pro and anti-regime parliamentary behavior in autocracies.

\subsection{Trading off electoral systems}

A first step in investigating the effect of elections on parliamentary behavior in autocracies is to realize that if electoral incentives matter, it naturally follows that elections will 
deferentially affect the incentives of parliamentarians depending on how the particular electoral system is designed. On the one hand, the ideal typical first-past-the-post race in a single-member district provides parliamentarians with incentives to push the interests of their local district. From the literature set in democracies, electoral systems have been found to affect the position-taking of deputies (Calvo and Hellwig 2011; Cox 1990), including to what extent deputies try to favor smaller, and geographically concentrated, groups of voters (Myerson 1993). In fact, cross-country evidence suggests that plurality systems in single-member districts generate more geographically targeted spending compared to systems with proportional party lists in larger, multi-member constituencies (Milesi-Ferretti et al. 2002; Persson et al. 2007).

Studying Italy, Gagliarducci et al. (2011) find that parliamentarians elected in a majoritarian system seek to push more geographically targeted bills in parliament than parliamentarians elected in a proportional party-list system. Such electoral system thereby delegates competencies over the selection of parliamentarians to local areas. Applying these insights in a non-democratic context, an electoral system with a local component allows the regime to open the door for local elites to join the parliamentary bargaining (Gandhi 2008). In return for favorable policies, these elites no longer pose a threat to the regime (Lust-Okar 2006). In addition, without the regime having to exert effort, elections efficiently open the door to parliament only for elites with the best capacity to mobilize votes locally (see Malesky and Schuler 2011 for elections in single-party regimes).

However, the benefits of loosening control over the selection of deputies come at the cost of reducing the regime's legislative control (Gandhi et al. 2019; Malesky and Schuler 2011). The engineering of the electoral system therefore presents autocrats with a dilemma (Gandhi and Heller 2018). Malesky and Schuler (2010) show how Vietnamese 
delegates nominated locally are more likely to criticize the regime during query sessions, as their future seat in parliament depends less on regime approval. This is especially so if their local principal has an interest in them opposing the regime to extract rents. These insights are consistent with classical accounts of how the specific configuration of the electoral system has consequences for party loyalty and the extent to which party elites exert control over deputies (Ames 1995; Carey and Shugart 1995).

This in turn changes the parliament's role from simply rubber stamping executive decisions to actively opposing the regime if need be. Such regime challenging behavior is unlikely in, say, a closed-list PR system, where the regime arguably has the most farreaching control over deputies in parliament (Gandhi et al. 2019). In a closed-list PR system, deputies are responsive to party elites (in effect the ruling regime in countries with a weak or systemic opposition), who determine the rank of candidates on the party list (Haspel et al. 1998). In such a system there is no incentive to oppose the regime, as such behavior will be punished through future nomination. However, there is likely less encouragement to facilitate parliamentary bargaining with local areas for personal votes as voters are are not able to elect individual candidates against the wishes of the party (Buisseret and Prato 2020; Chang and Golden 2007).

Devising the particular electoral system therefore taps into the dictator's electoral dilemma, and co-optation is consequently a balancing act (Svolik 2012). On the one hand, the regime has a preference for parliamentarians to be accountable to local elites, because it allows for parliamentary bargaining, in which parliamentarians pursue the interests of their local backer. On the other hand, parliamentarians with a distal principal simultaneously pose a challenge to the regime's legislative control. Parliamentarians thus balance on a knife's edge between representing the interests of outside actors while 
behaving in accordance with the wishes of the regime (Truex 2016).

\subsection{Observable implications}

If the specific electoral system matter, this will be reflected in the behavior of parliamentarians. In anticipation of the importance of local backing in future elections, parliamentarians elected in a single-member district are expected to be responsive to local interests. This leads to the first hypothesis:

\section{H1: Parliamentarians elected in a single-member district more often than} parliamentarians elected on a closed party list represent the interests of local districts

To further support the effect of elections, we would expect electoral incentives to be reflected also in the behavior of parliamentarians outside parliament. Though time demanding, constituency visits allow locally elected parliamentarians to form and maintain alliances with important local actors able to mobilize votes, and the parliamentarian comes to learn the preferences of local actors. ${ }^{5}$ This leads to the second expectation:

This is positive for the regime, as the regime is interested in designing an electoral system which facilitates parliamentary bargaining with powerful local opposition. However, when the preferences of the regime and local actors conflict, local representation may be at the expense of parliamentarians abiding by the ground rules set out by the regime, in turn weakening the regime's legislative control. Parliamentary bargaining therefore introduces an institutional trade-off as the presence of parliamentarians with strong principals outside parliament can challenge the regime, by obstructing the law making process. This leads to the final hypothesis:

H2: Parliamentarians elected in a single-member district more often than

\footnotetext{
${ }^{5}$ For constituency visits in democracies see Fenno 1978.
} 
parliamentarians elected on a closed party list try to obstruct law proposals

While the theoretical predictions generated above are clear, we have no empirical assessment of whether electoral incentives in autocracies are strong enough to shape parliamentary behavior. Before describing the empirical setup, the next section will describe the context of Russia.

\section{District deputies and local elites in Russia}

In Russia, local elites have historically had a strong grip on locally elected federal deputies. Understood as networks of local business leaders and regional bureaucrats organized around and led by governors, regional political machines played an important role in national politics (Hale and Orttung 2003). So important, that they have been argued to act as party substitutes (Hale 2005). Though weakened by an electoral reform in 2005, governors remained the most influential actor in Russian regional politics (Reuter 2013).

What made these local elites so powerful was their ability to exercise strong influence over local companies, which in turn mobilized votes on behalf of the governor, as well as for federal candidates endorsed by the governor (Frye et al. 2018, 2014, 2019; Gandhi et al. 2019). Governors exercised considerable power over companies in their respective region through the role as a major shareholder, and due to governors' informal control over the regional, executive bodies, including the tax police, the prosecutors office, procurement processes, and local courts (Hale 2007; Reuter 2013). It follows that local companies relied heavily on the goodwill of the governor in order to conduct their business. Governors also exercised complete control over appointments to the regional, executive bureaucracy and used this to strengthen patron-client relations by rewarding allies through patronage. In return, business owners and high-level bureaucrats would induce their employees to turn

out and vote according to the wishes of the governor (Reuter 2013). Such clientelistic 
networks are particularly effective at vote mobilization (Frye et al. 2014, 2019) and they made the governor machines highly effective at mobilizing votes (Hale 2007). ${ }^{6}$ In turn, the governor would get federal district deputies elected, and the backing of regional governors was one - if not the most - important factor determining the electoral success of district deputies (Hale 1999, see also Hale 2005). On average, several district deputies run for the State Duma within a federal region ${ }^{7}$, and governors have been shown to support several district deputies across district races within their region (Hale 1999). Hale (2007) even use district deputy vote shares to proxy for the strength of the regional machine.

\subsection{Parliamentary bargaining}

District deputies in the federal Duma often maintained strong links to the governor of their respective region post-election. District deputies' would introduce amendments in parliament reflecting their governor's interests to "pay back" for the votes mobilized by the governor (Hale and Orttung 2003). Although the Russian Duma has historically been weak vis-a-vis the executive (Remington 2008a), deputies have some sway over political outcomes by suggesting amendments to law proposals which (re)distribute resources to their local districts. Studying the State Duma, Noble (2017, p. 510) finds that "during legislative passage, spending is - on average - redistributed away from administration, defense, security and the economy to areas such as housing, education and social policy". The author notes that such amendments can be seen as help to regime-loyal deputies. The finding is supported by Krol (2017, p. 451), concluding that "loyal MPs systematically and substantially amend politically salient pieces of legislation". Through bargaining in

\footnotetext{
${ }^{6}$ The importance of governors' political machines is reflected in the sub-national parliamentary elections. Reuter (2013) demonstrates how the electoral fortune of the United Russia in regional legislatures - after the efforts to strengthen control with regional governors - depends on governors' political machines to mobilize votes.

${ }^{7}$ There are 89 federal regions and 225 single-member districts.
} 
parliament, the regime is able to meet demands from deputies and their local backers.

\subsection{Legislative control}

However, the regime sets the terms for the concessions. The Russian Duma is heavily controlled by the executive (Noble and Schulman 2018; Remington 2007, 2014), and the agenda is generally set by pro-presidential factions who shape majorities before items reach the floor (Remington 2008b). The regime's ability to steer the legislative agenda is exemplified by the presidential veto rate. For the period in which president Putin has held power, the convocation with most presidential vetoes saw four percent of legislation being vetoed (Remington 2014, p. 105), suggesting that the regime's preferences over law initiatives is overwhelmingly positive.

It follows that the regime favors a cooperative parliament that rubber-stamps law proposals born in the executive. Obstructing legislation is in effect opposing the regime. ${ }^{8}$ However, in the legislative bargaining between the regime and deputies, district deputies are unreliable coalition partners. Even though many district deputies joined the ranks of the United Russia - the regime party for most of the last two decades - their loyalty to the Kremlin was inferior to that of their regional bosses, and the regime was aware of this. For example, Igor Borisov, a previous member of the Central Electoral Commission, stated that "the regional representatives in the parliament, those elected in single-member-constituencies mostly defended not the interests of Russia as a whole but

\footnotetext{
${ }^{8}$ Even though Russia is characterized as a "super-presidential" system with widespread possibilities of using presidential decrees, uncollaborative deputies pose a significant problem. The constitution stipulates that only federal law can set policy in some areas, in which case the president must assemble a parliamentary majority in order to adopt a law. In addition, decrees are limited to areas not already covered by an existing law (see Remington 2014, p. 132) and decrees do not sideline the Duma: if a sufficiently strong coalition of legislators openly or tacitly defy a decree, it becomes ineffective (Remington 2014, p. 95). This goes to show that weak legislative control may necessitate decrees in the first place, and weak legislative control may subsequently weaken the effectiveness of decrees.
} 
rather the interests of regional political elites" (cited in Golosov 2017). Consequently, district deputies came to act as "sub-patrons" to the governor (Hale 2007).

District deputies therefore found themselves with conflicting interests, as powerful local backers demanded that deputies opposed measures supported by the president (Remington 2006). In the parliamentary bargain, the weakly disciplined district deputies required pork-barrel concessions in return for supporting the regime's legislative agenda (Moraski 2007), and obstructed legislation to their governor's disliking, if they felt bypassed. Due to party list deputies' reliance on party elites for a sufficient ballot rank, they were in no position to extract resources through law obstruction and party list deputies have also been shown to exhibit higher party loyalty (Kunicova and Remington 2008). Legislation addressing regional governance clearly illustrates this conflict, as regional governors had a strong interest in decentralized governance in direct opposition to the regime's interest in centralization (Hale and Orttung 2003). It follows that district deputies, even if officially supporting the regime, would only form unreliable coalitions: they were regime loyal only to the extent that the position did not conflict with the wishes of their local patrons, who effectively elected them.

\section{Data and measurement}

In order to measure electoral incentives we rely on data on list affiliation from the Russian Central Election Commission. The government gazette (Rossiskaia Gazeta) publishes lists of candidates as they become official in the months preceding each election. We collected 10,500 candidates registered in single-member districts and 32,000 candidates on party lists, starting from the election in 1993 and including the most recent 2016 
elections. Records are primarily obtained through archival research. ${ }^{9}$ Dual included deputies (elaborated below) were identified as parliamentarians who registered on both the party list and in a distract race in the same election.

Data on outcomes are from two different sources. To measure parliamentary bargaining on the Duma floor, we study whether district deputies are more likely to push local amendments through parliamentary speeches. The State Duma stores more than 50,000 documents corresponding to the population of transcribed points on the agenda. After extracting speeches from each unique deputy on each issue, the data set consists of 165,000 unique deputy-topic speeches in parliament. Official transcripts of all speeches are available from 1993 to the present day. We create a deputy-specific dictionary, taking the form of a matrix in which rows are individual deputies, and columns are locations within the deputy's home region. Local amendments are thus measured as the total number of times a deputy refer to her own region in a given speech. To identify deputyregion linkages, we rely on the 2010 Russian census, which contains information on the population of Russian federal districts, regions, urban settlements, and rural settlements with a population of three-thousand residents or more. An average of 82 (median of 68) locations per region are identified. The measure consequently picks up if a deputy speaks about her own region. For robustness, we re-run the whole analysis using instead a supervised classifier, trained on 4,000 hand coded speeches. This robustness measure specifically classifies speeches if they contain a local, distributive preference (see Section D). ${ }^{10}$

To measure legislative control, we rely on official voting records. The data include

\footnotetext{
${ }^{9}$ Data on candidate lists in the 1993 election was kindly made available by Thomas Remington (see e.g. Remington and Smith 1996). We are also grateful to John Ora Reuter for kindly sharing data on governor electoral results (see Reuter 2013; Reuter and Robertson 2012).

${ }^{10}$ Official data available at http://api.duma.gov.ru/pages/api.
} 
just short of 8,000 official roll call votes (all law stages), including the action of each deputy, available from 2000. As any voting action different from an explicit "yes" is in effect a "no", an absolute majority (226 out of 450 votes) is required to approve a motion on a law. In the following, obstructing a vote is therefore understood as either abstaining from voting, being absent from a vote, or voting against. ${ }^{11}$

\section{List affiliation}

Russia presents an ideal laboratory to study the effect of different electoral systems. Whereas, 225 federal deputies are elected in a first-past-the-post system in 225 singlemember districts, 225 federal deputies are elected on a nationwide, closed party list through PR. Seats are filled through separate ballots: that is, Russian voters cast two votes, one for each list (Remington and Smith 1996). ${ }^{12}$ Consequently, district deputies are encouraged to cater to geographically defined, smaller constituencies (Motolinia 2020). In contrast, party list deputies are accountable to, if not the national electorate (deputies ranked within the top-twelve on the party list), then large regions (Sieberer 2010). Even then, larger district magnitudes and closed party lists tend to divert the interest of party list deputies towards party elites, who can directly decide the fate of the deputy (Moraski

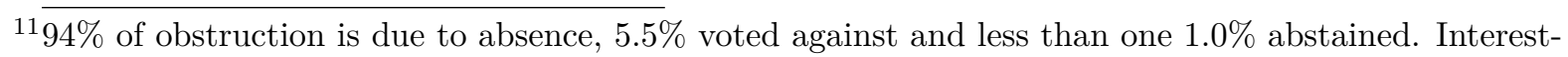
ingly, the two factions most actively voting against legislation are the communist party - CPRF- and the agro-industrial deputy faction, voting against legislation in $7.6 \%$ and $9.0 \%$ of the roll call votes, respectively, compared to the average of $2.0 \%$. These factions are historically elected on an anti-regime platform. Voting directly against legislation is therefore a signal to core constituents. In contrast, independent candidates (overwhelmingly district deputies) voted against legislation in only $3 \%$ of cases, reflecting that district deputies are not clearly elected on an anti-regime platform. Instead, independent candidates are absent $70 \%$ of the time, compared to an average of $36.6 \%$, the highest for any faction. As proxy voting is possible, not supporting legislation is likely a deliberate choice. United Russia deputies score below average with respect to obstructing legislation: United Russia deputies are voting against only $0.5 \%$ of legislation and are absent for only $30.7 \%$.

${ }^{12}$ Table A.2 in Appendix shows the number and electoral success rate of dual candidates.
} 
2007). If a party list deputy sway too far from the party line, the party leadership can directly sanction the deputy with a lower rank on the party list in the subsequent election. It follows that party list deputies will be hesitant to advance the interests of narrow, local constituencies, as such behavior will be punished by the neglected parts of the constituency or by party elites. Single-member district deputies do not face such constraints. The dynamic is further enforced by the insight that party list constituencies are rarely concentrated geographically. As shown in Figure 1, the system was in place from 1993-2007 and reintroduced prior to parliamentary elections in 2016. In the period 2007-2016, a pure party list system was in place.

Figure 1: Deputies and list affiliation in the Russian Duma

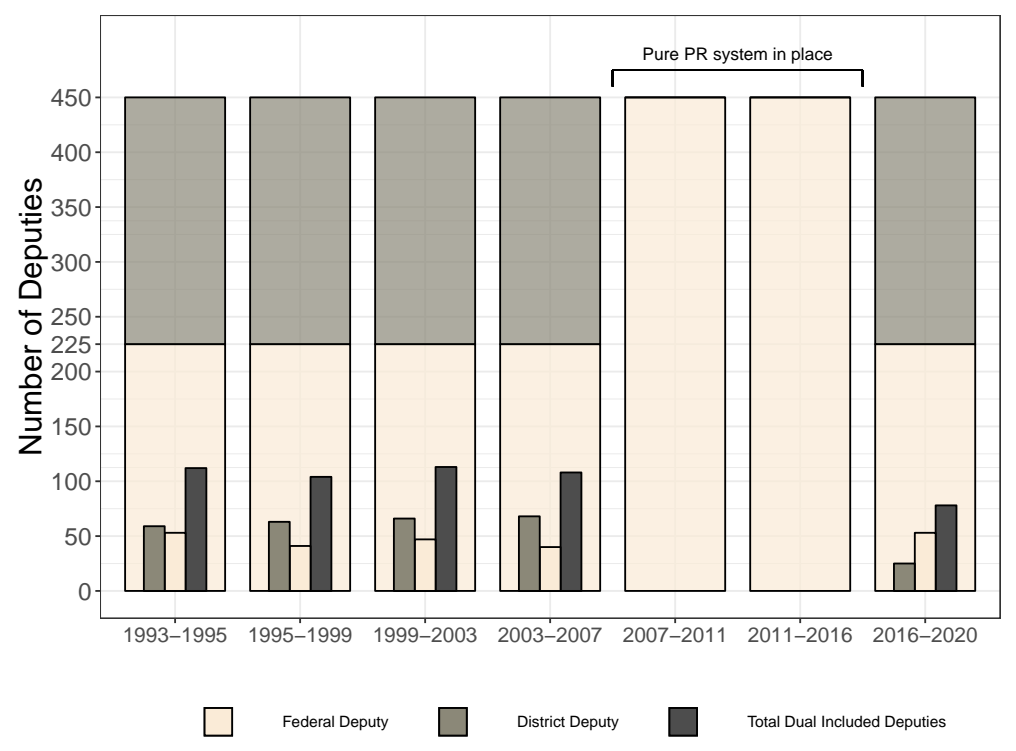

Importantly, incentives from one list do not affect incentives on the other. Whereas the closed-list nature of the federal party list system provides party elites with tight control over access, parties exert much less control in the single-member districts (Sieberer 2010; Bawn and Thies 2003). ${ }^{13}$ Additionally, district votes do not determine ranking on

\footnotetext{
${ }^{13} \overline{\text { District candidates can obtain nomination }}$ either through signatures or party nomination. However even if nominated by parties, district candidates tend to have strong regional ties, which can lead them to favor regional interests over federal ones (Moraski 2007).
} 
the party list. The two branches are also not interlocked into one system by compensatory seats. Instead, seats are allocated according to the results for each list separately. The setup presents a unique opportunity to investigate how a regime has to trade off components of distinct electoral systems, holding constant confounders including culture, institutions, and history. By doing so, the design follows in a line of innovative contributions exploiting within-country institutional peculiarities to explore the effects of electoral systems generally (Desposato 2006; Gagliarducci et al. 2011; Haspel et al. 1998).

\subsection{Causal identification}

Observing differences in parliamentary behavior across list affiliation tells us little about how elections matter. Any difference risks resulting from particular candidate types systematically selecting into one tier (Malesky and Schuler 2011; Motolinia 2020). Generally, it may be that district seats appeal to candidates driven by local issues, without elections themselves having any disciplinary power (Gagliarducci et al. 2011). Anecdotal evidence from Russia suggests that business candidates with deceitful motivations tend to register in the districts (The Washington Post 1999). It follows that list affiliation may pick up other explanations than merely electoral incentives.

To isolate the effect of electoral incentives on behavior, this paper takes advantage of an original approach to gauging the effect of distinct authoritarian electoral systems: the institutional phenomenon of double inclusion. Double inclusion permits parliamentary candidates to register on both electoral lists simultaneously. Final list affiliation for dual included candidates is determined exclusively by the margin of victory (MV) in the single-member district. The list assignment rule is deterministic: for $M V_{i}>0$, a dual candidate is assigned the district seat and the party list seat is freed up. ${ }^{14}$ Conversely,

\footnotetext{
${ }^{14} \overline{\text { This is except the 1993-election in which }}$ district deputies could choose. However, nearly all chose a district seat and freed up the party list seat (Remington and Smith 1996).
} 
for $M V_{i}<0$ the dual candidate is assigned the party list seat if her rank on the federal party list is sufficient. Gagliarducci et al. (2011) use a similar setup to parse out electoral effects in Italy, a consolidated democracy. However, they compare dual included federal list candidates to all district candidates. This paper is able to identify dual candidates on both lists.

The intuition behind double inclusion as a regression discontinuity, illustrated in Figure 2 , is that dual candidates have selected into both electoral tiers, thus holding constant selection. Variation in deputy behavior across lists will then be explained by different incentives emanating from different demands from constituencies, not deputy characteristics per se. The plausibility of this assumption increases as $M V_{i} \rightarrow 0$. Dual candidates immediately above and below the electoral threshold become each other's counterfactual: they are identical in terms of characteristics, the sole difference being the list they are eventually elected on. In total, 515 dual candidates were identified out of a total of 2744 politicians $\quad(20 \%)$ across five convocations.

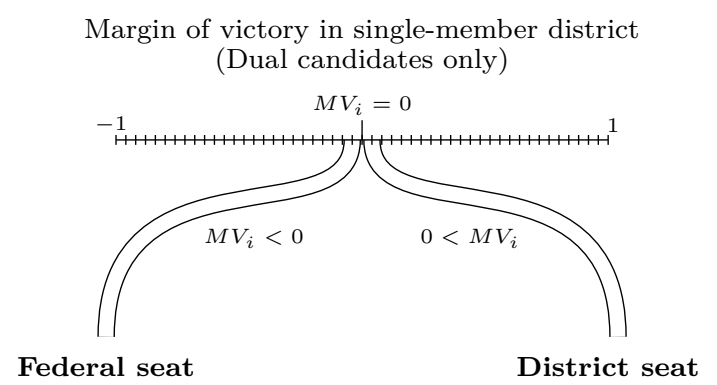

Figure 2: Dual candidates and the discontinuity in electoral incentives

The effect is mechanically estimated for deputies in competitive districts, but this in no way deems the effect inconsequential. Russian district elections are thus characterized by a noticeable degree of competition (see Figure A.5 in appendix). 


\subsection{Design assumptions}

The design presupposes that even if only marginally elected on either list, incentives with respect to constituency representation change abruptly. While this is an empirical question, it is plausible as cultivating two different constituencies is costly. Significant incumbent advantages urge politicians to focus on the district, where they stand the best chance of winning: the seat they currently claim. Mobilizing votes among new constituencies requires beginning from a clean slate (Crisp and Desposato 2004). This is supported in the data. Accounting for the forced list changes following the elimination and reintroduction of the mixed system, 76 percent of dual included deputies reclaiming office in the subsequent election, won their seat on the same list. Finally, split campaigning washes out effects of list affiliation, making estimates conservative.

Table 1 explores balance on observables. If list assignment is truly as-if random for margins of victory close to zero, covariates are discontinuous in expectation: that is, a dummy variable taking on a value of 1 for $M V_{i}>0$, and 0 for $M V_{i}<0$ should not be correlated with background variables. ${ }^{15}$ Generally, there seems to be no systematic pre-treatment differences across covariates close to the threshold. Seniority, which is the most persistently statistically significant imbalance, is only significant until a margin of victory of 0.35 . For smaller bandwidths, the sign of the coefficient becomes quite volatile. Controlling for seniority does not change the results.

\footnotetext{
${ }^{15} \overline{\text { The specification follows equation } 1 \text { below. }}$.
} 
Table 1: Balance on Observables

\begin{tabular}{|c|c|c|c|c|}
\hline \multirow[b]{2}{*}{ Bandwidth } & \multicolumn{4}{|c|}{ Seniority } \\
\hline & 1 & 0.35 & 0.25 & 0.15 \\
\hline$S M D$ & $\begin{array}{c}-0.18^{* *} \\
(0.09)\end{array}$ & $\begin{array}{c}-0.26^{* * *} \\
(0.10)\end{array}$ & $\begin{array}{c}-0.22^{* *} \\
(0.11)\end{array}$ & $\begin{array}{l}-0.04 \\
(0.14)\end{array}$ \\
\hline \multirow[t]{2}{*}{$\underline{\mathrm{N}}$} & 515 & 428 & 345 & 213 \\
\hline & \multicolumn{4}{|c|}{ District size (k) } \\
\hline$S M D$ & $\begin{array}{c}-4.28 \\
(9.52) \\
515\end{array}$ & $\begin{array}{c}-15.77 \\
(10.36) \\
428\end{array}$ & $\begin{array}{c}-4.73 \\
(11.48) \\
345\end{array}$ & $\begin{array}{c}0.71 \\
(16.18) \\
213\end{array}$ \\
\hline $\mathrm{N}$ & \multicolumn{4}{|c|}{ Age } \\
\hline$S M D$ & $\begin{array}{c}2.01 \\
(1.63)\end{array}$ & $\begin{array}{l}-1.90 \\
(2.01)\end{array}$ & $\begin{array}{c}-4.68^{* *} \\
(2.21)\end{array}$ & $\begin{array}{c}-5.28^{* *} \\
(2.44)\end{array}$ \\
\hline \multirow[t]{2}{*}{$\mathrm{N}$} & 493 & 406 & 325 & 199 \\
\hline & \multicolumn{4}{|c|}{ Rank, PR list } \\
\hline$S M D$ & $\begin{array}{c}8.51 \\
(5.29) \\
406\end{array}$ & $\begin{array}{c}9.58 \\
(7.06) \\
350\end{array}$ & $\begin{array}{c}9.18 \\
(8.94) \\
287\end{array}$ & $\begin{array}{c}2.68 \\
(13.94) \\
173\end{array}$ \\
\hline $\mathrm{N}$ & \multicolumn{4}{|c|}{ District location } \\
\hline \multirow[t]{2}{*}{$S M D$} & $\begin{array}{c}-12.81 \\
(9.11) \\
515\end{array}$ & $\begin{array}{c}-2.59 \\
(11.77) \\
428\end{array}$ & $\begin{array}{c}-2.43 \\
(13.73) \\
345\end{array}$ & $\begin{array}{c}6.29 \\
(18.27) \\
213\end{array}$ \\
\hline & \multicolumn{4}{|c|}{ Woman } \\
\hline$S M D$ & $\begin{array}{c}0.02 \\
(0.05) \\
515\end{array}$ & $\begin{array}{c}-0.06 \\
(0.07) \\
428\end{array}$ & $\begin{array}{c}-0.06 \\
(0.09) \\
345\end{array}$ & $\begin{array}{c}0.04 \\
(0.12) \\
213\end{array}$ \\
\hline $\mathrm{N}$ & \multicolumn{4}{|c|}{ PR regional sublist } \\
\hline$S M D$ & $\begin{array}{c}0.01 \\
(0.03) \\
515\end{array}$ & $\begin{array}{c}0.04 \\
(0.04) \\
428\end{array}$ & $\begin{array}{c}0.001 \\
(0.05) \\
345\end{array}$ & $\begin{array}{c}0.03 \\
(0.07) \\
213\end{array}$ \\
\hline $\mathrm{N}$ & \multicolumn{4}{|c|}{ United Russia } \\
\hline$S M D$ & $\begin{array}{c}0.03 \\
(0.04) \\
515\end{array}$ & $\begin{array}{c}0.02 \\
(0.04) \\
428\end{array}$ & $\begin{array}{c}0.01 \\
(0.05) \\
345\end{array}$ & $\begin{array}{c}-0.01 \\
(0.07) \\
213\end{array}$ \\
\hline $\mathrm{N}$ & \multicolumn{4}{|c|}{ Rural population (k, region) } \\
\hline$S M D$ & $\begin{array}{c}-102.99 \\
(99.46) \\
381\end{array}$ & $\begin{array}{c}-77.45 \\
(133.39) \\
314\end{array}$ & $\begin{array}{c}-104.38 \\
(157.84) \\
252\end{array}$ & $\begin{array}{c}-242.20 \\
(220.91) \\
158\end{array}$ \\
\hline $\mathrm{N}$ & \multicolumn{4}{|c|}{ Registered in Moscow or Sct. Petersburg } \\
\hline \multirow[t]{2}{*}{$S M D$} & $\begin{array}{c}-0.15^{* *} \\
(0.07) \\
515\end{array}$ & $\begin{array}{c}-0.13 \\
(0.09) \\
428\end{array}$ & $\begin{array}{c}-0.06 \\
(0.10) \\
345\end{array}$ & $\begin{array}{c}-0.09 \\
(0.14) \\
213\end{array}$ \\
\hline & \multicolumn{4}{|c|}{ Governor vote margin } \\
\hline$S M D$ & $\begin{array}{c}-8.74^{* *} \\
(4.39) \\
515\end{array}$ & $\begin{array}{c}-3.81 \\
(5.48) \\
428\end{array}$ & $\begin{array}{c}-3.78 \\
(6.40) \\
345\end{array}$ & $\begin{array}{c}-4.73 \\
(8.99)\end{array}$ \\
\hline & & Govern & eniority & \\
\hline$S M D$ & $\begin{array}{c}0.53 \\
(0.55)\end{array}$ & $\begin{array}{c}0.15 \\
(0.62)\end{array}$ & $\begin{array}{c}0.38 \\
(0.71)\end{array}$ & $\begin{array}{c}1.32 \\
(1.04)\end{array}$ \\
\hline $\mathrm{N}$ & 515 & 428 & 345 & 213 \\
\hline & & Elect & fraud & \\
\hline$S M D$ & $\begin{array}{c}0.04 \\
(0.43) \\
515\end{array}$ & $\begin{array}{c}-0.50 \\
(0.54) \\
428\end{array}$ & $\begin{array}{c}-0.19 \\
(0.63) \\
345\end{array}$ & $\begin{array}{c}0.92 \\
(0.82) \\
213\end{array}$ \\
\hline $\begin{array}{l}\text { Notes: }{ }^{*} \mathrm{p} \\
S M D+M \\
\text { size proxi } \\
\text { for distric } \\
\text { in parliam } \\
\text { registered } \\
\text { is the vote } \\
\text { proxied as } \\
\text { errors clus } \\
\text { the convor }\end{array}$ & $\begin{array}{l}* * \mathrm{p}<.05 \\
S M D * M \\
\text { total vote } \\
\text { ation. Sen } \\
\text { PR regior } \\
\text { he federal } \\
\text { re of the } \mathrm{r} \\
2 \text { nd decin } \\
\mathrm{d} \text { at the de } \\
\text { n level. }\end{array}$ & $\begin{array}{l}<.01 \text {. All } \\
\text { Only the fir } \\
\text { the distric } \\
y \text { is measu } \\
\text { ublist indi } \\
\text { of the Pf } \\
\text { ctive gove } \\
\text { igit of the } \\
\text { y-congocat }\end{array}$ & $\begin{array}{l}\text { els of the } \\
\text { rm is rep } \\
\text { istrict nu } \\
\text { as days si } \\
\text { whether } \\
\text { Govern } \\
\text { Electora } \\
\text { aty's vote } \\
\text { evel. Fix }\end{array}$ & $\begin{array}{l}\text { n } y= \\
\text { d. District } \\
\text { is used } \\
\text { irst day } \\
\text { deputy is } \\
\text { te margin } \\
\text { ud is } \\
\text { gin. Std } \\
\text { fects at }\end{array}$ \\
\hline
\end{tabular}


Table 2 shows the distribution of the margin of victory for all 515 dual candidates identified. Worth noting is the lower share of party list candidates close to 0 . The asymmetry in treatment assignment could be caused by district deputies having to win only the district seat, whereas dual included federal list deputies need to both lose the district seat and enjoy a rank on the party list sufficient for election. This also seems to explain the jump in density around the threshold in Figure A.4 in appendix. Importantly, Table 1 suggests that party list rank is in fact balanced across lists. To further address potential sorting issues, Table A.3 runs the specification 1) with party fixed effects and 2) excluding observations close to the threshold. Results are unchanged. Finally, Table A.1 in appendix suggests that dual included deputies are not considerably different from other deputies in terms of background characteristics.

Table 2: Distribution of the margin of victory for dual candidates

\begin{tabular}{|lrrr|}
\hline & \multicolumn{2}{c}{ Observations } & $\begin{array}{r}\text { Share of dual deputies } \\
\text { elected on party list }\end{array}$ \\
\hline$M V_{i}$ & 515 & 40,285 & .45 \\
$M V_{i} \in[-.3, .3]$ & 396 & 29,687 & .44 \\
$M V_{i} \in[-.2, .2]$ & 291 & 22,122 & .40 \\
$M V_{i} \in[-.1, .1]$ & 158 & 11,497 & .33 \\
$M V_{i} \in[-.05, .05]$ & 67 & 4,406 & .28 \\
$M V_{i} \in[-.01, .01]$ & 14 & 1,109 & .07 \\
\hline
\end{tabular}

Note: data included covers 1993-2007 and 2016-2019.

\section{Estimation}

In order to isolate the effect of list affiliation, the following regression-discontinuity equation is estimated:

$$
R_{i c}=\beta_{1} S M D_{i c}+\beta_{2} M V_{i c}+\beta_{3} S M D_{i c} \times M V_{i c}+\varepsilon
$$

$R_{i c}$ is the outcome of deputy $i$ in convocation $c$ as measured in speeches, constituency visits, and law obstruction. $M V_{i c}$ is the margin of victory in the single member district, 
defined as the difference between the vote share of $i$ and the vote share of the district runner-up (or winner), given in percentages of total votes cast in the district. $S M D_{i c}$ takes the value of 1 if $M V_{i c}>0$ and 0 otherwise. As list affiliation is assigned at the deputy-convocation level, the analysis is run at the convocation level by averaging outcomes within convocations. Equation 1 is estimated with convocation fixed effects and standard errors clustered at the deputy-convocation level, and is estimated for varying bandwidths $M V_{i} \in[-b w,+b w]$. In Equation 1, $\beta_{1}$ is the coefficient of interest: expected to be positive when outcomes measure representation of local districts, and negative when measuring law obstruction. The model is estimated for two subsets of the data. Sample 1 is closest to achieving a true counterfactual, by including only dual included deputies. Sample 2 follows Gagliarducci et al. (2011) by including all district deputies (dual included or not), as well as dual included party list candidates. Effects are comparable across subsets, though the second specification provides a larger sample and, consequently, more statistical power. All models control for the pre-treatment variables gender and age to increase statistical power.

\section{Results}

The first part of the analysis studies parliamentary behavior during the first period with the mixed-member system in place. Consequently, data after the introduction of the pure PR system for the 2007 general elections are excluded. Section 8 introduces data from after 2016 in order to assess changes in deputy behavior over time.

\section{Local amendments}

Table 3 addresses Hypothesis 1 by estimating the effect for dual included deputies of being elected in a single-member district vis-a-vis the party list on the likelihood that the deputy suggests initiatives favoring local constituencies on the Duma floor. Following 
Section 6, equation 1 is estimated for dual included deputies only, as well as including all deputies who ran in a district (irrespective of whether they were dual included or not). Interpreting Table 3 as a whole, the effect of district affiliation is positive and robust across both subsets, as well as across all but the smallest bandwidths. Effect sizes vary slightly, but district deputies generally mention their home region 0.15 to 0.25 times more per speech on average. Effect sizes are substantial and make up approximately a third to half of a standard deviation in the dependent variable. For intuition, effect sizes suggest that district deputies mention their district in approximately two out of three speeches, while party list deputies push local amendments in every fourth speech. ${ }^{16}$

Interpreting the third and fourth rows indicate that results are also robust to the alternative outcome, which measures local amendments using a supervised classifier trained on 4,000 hand coded speeches (elaborated in Section D in appendix). Estimations with the robustness measure suggest that district deputies are twice as likely to push local amendments. In this alternative measure, local amendments have to be explicitly distributive. Though this is not a requirement for the measure in the first and second row of Table 3, the similar results suggest that distributive, local amendments play an important role. ${ }^{17}$ This suggests that the effect is practically significant: district deputies push local issues significantly more on the Duma floor.

Much like other parliaments in non-democracies, the Russian Duma thus seems to be a forum for the regime and elites to bargain over policy. Deputies present the conditions of their local backers with the hope that their plea is heard by the executive. These results

\footnotetext{
${ }_{16}$ Across specifications, party list deputies refer to local amendments 0.25 to 0.29 times per speech, while district deputies refer to local amendments 0.46 to 0.68 times per speech.

${ }^{17}$ The seemingly smaller effect sizes for the alternative measure are due to the supervised classifier being quite conservative in its classification of texts as local, distributive. This issue is elaborated in Section D.
} 
Table 3: Local Amendments

\begin{tabular}{|c|c|c|c|c|}
\hline \multirow[b]{2}{*}{ Bandwidth } & \multicolumn{4}{|c|}{ Sample 1} \\
\hline & $\Delta \mu$ & 0.35 & $0.25^{*}$ & 0.15 \\
\hline$S M D$ & $\begin{array}{c}0.08 \\
(0.05)\end{array}$ & $\begin{array}{c}0.32^{* *} \\
(0.13)\end{array}$ & $\begin{array}{c}0.17 \\
(0.13)\end{array}$ & $\begin{array}{c}0.17 \\
(0.16)\end{array}$ \\
\hline$\overline{\sigma_{y}}$ & 0.55 & 0.55 & 0.52 & 0.58 \\
\hline $\bar{y}_{0}$ & 0.29 & 0.29 & 0.25 & 0.29 \\
\hline \multirow[t]{2}{*}{$\mathrm{N}$} & 426 & 367 & 304 & 198 \\
\hline & \multicolumn{4}{|c|}{ Sample 2} \\
\hline$S M D$ & $\begin{array}{c}0.16^{* * *} \\
(0.06)\end{array}$ & $\begin{array}{c}0.39^{* * *} \\
(0.14)\end{array}$ & $\begin{array}{c}0.25^{*} \\
(0.15)\end{array}$ & $\begin{array}{c}0.20 \\
(0.20)\end{array}$ \\
\hline$\overline{\sigma_{y}}$ & 0.87 & 0.87 & 0.9 & 1.01 \\
\hline $\bar{y}_{0}$ & 0.29 & 0.29 & 0.25 & 0.29 \\
\hline \multirow[t]{2}{*}{$\mathrm{N}$} & 899 & 766 & 658 & 473 \\
\hline & \multicolumn{4}{|c|}{ Sample 1 (2nd measure) } \\
\hline$S M D$ & $\begin{array}{c}0.03^{* * *} \\
(0.01)\end{array}$ & $\begin{array}{c}0.04^{* * *} \\
(0.01)\end{array}$ & $\begin{array}{c}0.05^{* * *} \\
(0.01)\end{array}$ & $\begin{array}{c}0.07^{* * *} \\
(0.02)\end{array}$ \\
\hline$\sigma_{y}$ & 0.07 & 0.07 & 0.07 & 0.08 \\
\hline $\bar{y}_{0}$ & 0.04 & 0.04 & 0.04 & 0.04 \\
\hline \multirow[t]{2}{*}{$\mathrm{N}$} & 436 & 376 & 312 & 202 \\
\hline & \multicolumn{4}{|c|}{ Sample 2 (2nd measure) } \\
\hline$S M D$ & $\begin{array}{c}0.03^{* * *} \\
(0.005)\end{array}$ & $\begin{array}{c}0.03^{* * *} \\
(0.01)\end{array}$ & $\begin{array}{c}0.03^{* * *} \\
(0.01)\end{array}$ & $\begin{array}{c}0.05^{* * *} \\
(0.02)\end{array}$ \\
\hline$\sigma_{y}$ & 0.08 & 0.08 & 0.08 & 0.08 \\
\hline $\bar{y}_{0}$ & 0.04 & 0.04 & 0.04 & 0.04 \\
\hline $\mathrm{N}$ & 916 & 782 & 673 & 481 \\
\hline
\end{tabular}

Notes: ${ }^{*} \mathrm{p}<.1 ;{ }^{* *} \mathrm{p}<.05 ;{ }^{* * *} \mathrm{p}<.01$. Models in column $2: 7$ of the form $y=S M D+M V+$ $S M D * M V$, but only the first term is reported. Models control for age, and gender. Column 1 is the difference in means for $b w=1$. Dependent variable is the ratio of speeches containing a local, distributive amendment across the whole convocation. Std.errors clustered at the deputy-convocation level (i.e. level of treatment assignment), and convocation fe. For robustness measure see Section D. $\left(^{*}\right)$ indicates optimal bandwidth following Calonico et al. 2014. 
furthermore provide an explanation for what drives deputies to do this: specifically that list affiliation is able to provide deputies with incentives to cater to distinct constituencies. Results are robust to specifications with no fixed effects, party fixed effects, as well as at the individual speech level (see Table A.3 in appendix). Whereas the substantial effect size is to be expected in a democratic setting (Gagliarducci et al. 2011), results do suggest that Russian elections could matter more than the public perception would have them to.

\section{Obstruction of law proposals}

Table 3 suggests that single-member districts are an advantage to authoritarian regimes, because local representation allows regimes to obtain information on preferences of local elites (Gandhi 2008; Gandhi and Przeworski 2007). In contrast, Table 4 indicates that this type of institutional setup comes with a cost of weakened legislative control. Specifically, district deputies tend to obstruct the lawmaking process. Recall how law proposals in the Russian Duma are often pre-cleared by a pro-presidential coalition, or initiated specifically by the president, before reaching the floor. Failing to push legislation forward is therefore directly in opposition to the wishes of the regime. Realizing this, the regime prefers legislators who are consistently loyal to those with wavering support (Moraski 2007), as this strengthens legislative control (Golosov 2017).

Table 4 strongly suggests that district deputies are more unreliable when it comes to having legislation rubber stamped in the Duma. Across the two subsets, as well as across bandwidths, district deputies are 10-24 percent more likely to obstruct a given law proposal, thus supporting Hypothesis $3 .{ }^{18}$ Not only is the effect statistically significant, it also carries practical importance: a conservative estimate suggests that list affiliation

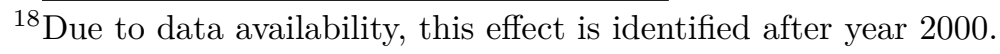


explains half of the standard deviation in deputies likelihood to obstruct legislation, and sometimes closer to three-fourths of a standard deviation. The result is consistent with Gandhi et al. (2019) who find that the introduction of a pure PR system in Russia with effect from 2007, increased control with federal deputies.

Table 4: Voting Obstruction

\begin{tabular}{|c|c|c|c|c|}
\hline \multirow[b]{2}{*}{ Bandwidth } & \multicolumn{4}{|c|}{ Dual Candidates } \\
\hline & $\Delta \mu$ & $0.35^{*}$ & 0.25 & 0.15 \\
\hline$S M D$ & $\begin{array}{c}0.04 \\
(0.03)\end{array}$ & $\begin{array}{c}0.14^{* *} \\
(0.06)\end{array}$ & $\begin{array}{c}0.18^{* * *} \\
(0.06)\end{array}$ & $\begin{array}{c}0.24^{* * *} \\
(0.09)\end{array}$ \\
\hline$\sigma_{y}$ & 0.26 & 0.26 & 0.26 & 0.27 \\
\hline $\bar{y}_{0}$ & 0.45 & 0.45 & 0.44 & 0.44 \\
\hline \multirow[t]{2}{*}{$\mathrm{N}$} & 397 & 341 & 287 & 187 \\
\hline & \multicolumn{4}{|c|}{ Dual and District Deputies } \\
\hline$S M D$ & $\begin{array}{l}0.04^{*} \\
(0.02)\end{array}$ & $\begin{array}{l}0.10^{* *} \\
(0.04)\end{array}$ & $\begin{array}{c}0.12^{* * *} \\
(0.05)\end{array}$ & $\begin{array}{c}0.17^{* * *} \\
(0.06)\end{array}$ \\
\hline$\sigma_{y}$ & 0.25 & 0.25 & 0.25 & 0.25 \\
\hline $\bar{y}_{0}$ & 0.44 & 0.44 & 0.43 & 0.42 \\
\hline $\mathrm{N}$ & 875 & 749 & 650 & 465 \\
\hline \multicolumn{5}{|c|}{$\begin{array}{l}\text { Notes: }{ }^{*} \mathrm{p}<.1 ;{ }^{* *} \mathrm{p}<.05 ;{ }^{* * *} \mathrm{p}<.01 . \text { Models in } \\
\text { column } 2: 7 \text { of the form } y=S M D+M V+ \\
S M D * M V \text {, but only the first term is reported. } \\
\text { Models control for age and gender. Column } 1 \\
\text { is the difference in means for bw }=1 \text {. Dependent } \\
\text { variable is the ration of absence to votes across } \\
\text { the whole convocation. Std.errors clustered } \\
\text { at the deputy-convocation level (i.e. level of } \\
\text { treatment assignment). }\left({ }^{*}\right) \text { indicates optimal } \\
\text { bandwidth following Calonico et al. } 2014 .\end{array}$} \\
\hline
\end{tabular}

Importantly, obstruction is not obviously a function of not being present in Moscow. Whereas district deputies travel significantly more to and from their home regions, there are no effects of list affiliation on total trips taken (Table A.4 in appendix). Presumably, party list deputies therefore spend an equal amount of time outside Moscow. As proxy voting is in fact permitted in the Russian State Duma, absence - making up the largest part of obstruction - seems a deliberate choice.

Figure 3 recaps the above results for the optimal bandwidth (Calonico et al. 2014). As all district deputies are included, there are mechanically more observations to the right (i.e. $M V>0)$. 

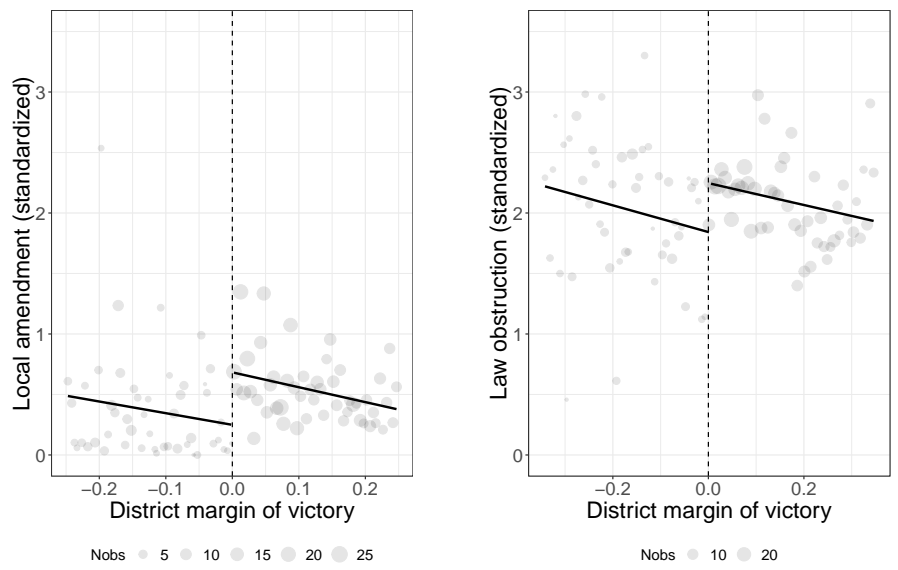

Figure 3: Illustrating the regression-discontinuity

Note: Bandwidths are optimal bandwidths (see Calonico et al. 2014). All district deputies in addition to dual included deputies are included. The middle plot only includes data from 2004 to 2006 (fourth convocation).

\section{Discussion}

Results suggest that the electoral system in place defines the parliament faced by the regime. A scenario where single member districts make up the electoral system (scenario one) results in 1,200-1,800 more speeches presenting local amendments per year compared to a scenario with a pure party-list PR electoral system (scenario two). While $42 \%-50 \%$ of total speeches are estimated to contain local amendments in scenario one, $25 \%$ of speeches would contain local amendments in scenario two (see appendix section E). At the same time, in scenario one deputies obstruct legislation $55 \%-62 \%$ of the time, compared to $43 \%-44 \%$ of the time in scenario two. The regime's collaboration with parliament is thus heavily shaped by the electoral system in place, and regimes face trade-offs in designing the electoral system: while electoral systems delegating competency over the selection of candidates to local areas provide a channel of information on local interests, the same local link makes deputies less likely to push legislation through parliament.

Managing this trade-off is a complicated task, and the results may help understand recent electoral reforms in Russia. The first such initiative was the reform of the electoral system, ratified in May 2005, which abandoned single-member districts all together 
(Moraski 2007). Instead, the regime adopted a pure PR electoral system, in place during two parliamentary sessions: from 2007 to 2011 and from 2011 to 2016. The reform simultaneously changed the electoral threshold from $5 \%$ to $7 \%$, it disallowed deputies to change legislative faction (Frye 2017), and it toughened the rules on party registration (Golosov 2017). The move was orchestrated by the president of the Russian Federation, Vladimir Putin (Remington 2008a), but faced heavy opposition in parliament (White and Kryshtanovskaya 2011). The second initiative, also adopted in 2005, abandoned direct, gubernatorial elections, and replaced them with presidential appointments (Reuter and Robertson 2012, Reuter 2013).

Scholarly consensus ascribes both reforms to a wish in the Russian regime to control regional patrons, who had become too powerful and exercised too much influence over district deputies, who in turn had become uncontrollable (Remington 2006) - a consensus consistent with the results above. The electoral reforms thus intended to strengthen federal control over parties and the legislature (Golosov 2017). This happened despite the fact that the move cost dearly at the ballot box (Gandhi et al. 2019; Reuter 2013).

Russia therefore presents a case in which the regime deliberately seems to have designed an electoral setup knowing about the challenges of different institutional components. Interestingly, a mixed-member system identical to the one previously in place was reintroduced again for the 2016 elections. The new institutional setup therefore begs the question of whether the Russian regime by re-designing the electoral institution overcame the trade-off: securing strong local representation, while simultaneously maintaining legislative control? Results suggest no. Thus, Figure 4 plots the effect of being marginally elected in a district vis-a-vis on the party list on the likelihood of suggesting local amendments and obstructing law proposals for two distinct periods: prior to abandoning the 
initial mixed-member system in 2007 and after the re-introduction of the mixed-member system for the seventh convocation (2016-2019).
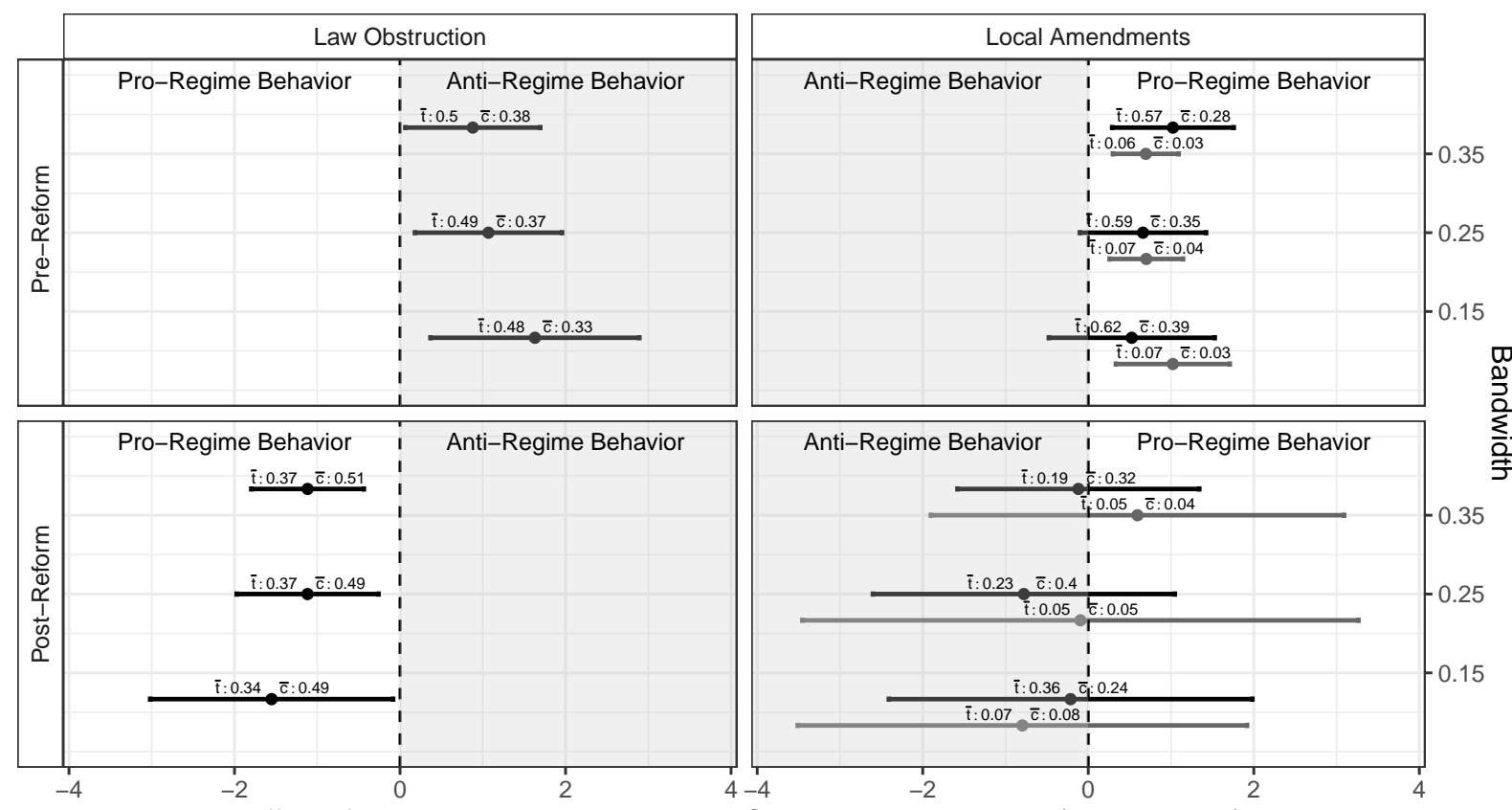

Effect of Being Marginally Elected in a Single-Member District (standardized)

Primary measure $\rightarrow$ Secondary measure

Figure 4: Assessing the trade-off over time

Note $\bar{t}$ and $\bar{c}$ indicate sample means for treatment and control group, respectively. Pre-reform period includes the years 1993-2007. Post-reform years include 2016-2019. Models correspond to the right hand side of Equation 1, with the outcome being law obstruction and local amendments, respectively. Effects sizes are shown in standard deviations for the whole period, which is 0.38 for local amendments and 0.12 for law obstruction.

Interpreting the first row in Figure 4 illustrates the trade-off discussed above. Whereas there is a positive effect of list affiliation on the tendency to present local amendments (pro-regime behavior), there is also a positive effect of district affiliation on the likelihood of obstructing law (anti-regime behavior). The two effect sizes furthermore seem to cancel out (law obstruction is approximately 0.9 standard deviations compared to 0.7 to 1 for local amendments). Turning to the left column, the reform initiatives have in fact strengthened legislative control. After the re-introduction of the mixed-member system, district deputies are now, not more, but less likely to obstruct legislation. In comparison, the inclination to obstruct law for party list deputies is rather stable prior to and after 
the re-introduction of the mixed member system (see Table A.5). Reform initiatives have therefore been successful in strengthening legislative control, but it seems to have been at the expense of the acquisition of information. Interpreting the right column in Figure 4, the effects of list affiliation on local amendments are dramatically reduced compared to the pre-reform period. Weaker links to local districts have plausibly made district deputies less likely to present local issues on the Duma floor. Whereas list affiliation accounts for half a standard deviation in the pre-reform period, list affiliation only accounts for one-tenth in the current convocation. This is ignoring the level of statistical uncertainty, which may partly be explained by smaller sample sizes (see Table A.5 in appendix).

Rationalizing the reform initiatives ex-post, results indicate that the Russian regime on the aggregate traded off a net neutral effect prior to reforms (the size of the antiregime effect cancels out the pro-regime effect), with a more than one-standard deviation pro-regime effect post reforms. This goes to show that even though regimes can trade-off positive and negative aspects of co-optation (and potentially gain a net-benefit), there is no obvious way to overcome the trade-off completely (Gandhi and Heller 2018).

\section{Concluding remarks}

Whereas the literature on electoral systems in consolidated democracies offers wellestablished expectations for parliamentary behavior (Cox 1990; Gagliarducci et al. 2011), we have little insight on their effects beyond democracies (Moraski 2007). Not only is this important for assessing representation and political accountability in electoral autocracies, the most common type of autocracy worldwide. Effects of particular electoral institutional designs also carry vital importance in order to understand the considerations of autocrats when designing electoral infrastructure.

This paper develops a theoretical framework in which electoral systems matter for 
parliamentary behavior in electoral autocracies, but introduce both benefits and costs to the incumbent regime. Consequently, incumbents will have to trade off these benefits and costs in their efforts to design optimal political institutions. Specifically, we argue that a local representative component of an electoral system - exemplified by district deputies in Russia - facilitates the representation of local elite demands on the parliamentary floor. Such local representation is crucial to the regime, because it is a necessary prerequisite for parliamentary bargaining. However, it comes at a cost. District deputies risk being hijacked by local demands, in turn weakening the regime's legislative control, instead of simply rubber stamping executive decisions.

In order to parse out the effect of list affiliation, we take advantage of the Russian mixed-member electoral system. Here, 225 deputies are elected in single-member districts, and 225 are elected on a party list. If elections were to matter, we would expect the different electoral components to result in stark differences in deputy behavior. Candidates campaigning for a seat in the Russian State Duma can register on both lists simultaneously, with the final seat determined by the margin of victory in the singlemember district. Double inclusion provides a framework for identifying the effect of list affiliation, by comparing double included district deputies barely elected in the singlemember district, to double included party list candidates who almost, but eventually did not, win the district. The identifying assumption is that these deputies are, on average, each other's counterfactual, identical in all other respects than list affiliation, an assumption which the paper empirically supports. The design is unique in that it allows for an assessment of electoral institutional trade-offs faced by the same regime at the same time, under the same circumstances.

The empirical results support that authoritarian regimes may indeed face a trade-off 
when designing electoral institutions. The study finds substantial and robust effects of being marginally elected in a district (vis-a-vis on the party list) on suggesting amendments favorable to local constituencies. Effect sizes vary around half a standard deviation in the dependent variable, and in some specifications reach close to one standard deviation. The results are robust across a variety of bandwidths, across party and convocation fixed effects, at different units of analysis, for excluding United Russia candidates, and to an alternative measure of local amendments. However, information comes at a cost: deputies barely elected in a district are thus 10-24 percent more likely to obstruct legislation, thereby increasing parliamentary resistance faced by the regime. This strongly suggests that too strong deputy-constituency linkages weaken the regime's legislative control.

The Russian case draws interesting perspectives to the trade-offs faced by an authoritarian regime seeking to prolong its rule. Deputies walk a fine line between representing their constituency and abiding by the unwritten rules laid out by the regime (Truex 2016). In Russia, the balance tipped: near the end of the 1990s deputies were perceived to be too close to regional political machines headed by governors. Consequently, in 2005, the Russian regime adopted an electoral reform abandoning the single-member districts altogether, instead replacing the mixed-member system with a pure party list PR system. After nine years with the pure party list system, the mixed-member system was reinstated prior to the 2016-elections. In the preceding period, the Russian regime weakened regional elites, an act which seems to have modified the trade-off. Thus, in the current convocation, deputies marginally elected in a district are 10-15 percent less likely to obstruct legislation. However, the trade-off is not overcome, as the initiatives simultaneously seem to have taken a toll on district deputies' likelihood of representing their local constituents on the Duma floor. 
We believe our results add to the literature on authoritarian politics in at least two respects. First, our results support that elections can have real consequences for politics in authoritarian countries by defining whom parliamentarians are accountable to. This is true even when only comparing parliamentarians who were willing to register across electoral lists. Second, realizing that elections matter directs attention towards how autocrats may benefit from strategically manipulating rules governing them. We theorize - and empirically support - a trade-off between information on local interests and control with parliamentarians. Doing this we illustrate how autocrats' choices over institutions may be suboptimal at best (Gandhi et al. 2019). Importantly, political institutions tend to come in bundles. By only investigating one - although a central - political institution, we are unable to theorize whether a combination of particular institutions may overcome the trade-offs imposed by any single institution, thereby unequivocally consolidating the power of the autocrat. This question presents a natural next step. 


\section{References}

Ames, Barry (1995). "Electoral strategy under open-list proportional representation". In: American Journal of Political Science, pp. 406-433.

Bawn, Kathleen and Michael F Thies (2003). "A comparative theory of electoral incentives: representing the unorganized under PR, plurality and mixed-member electoral systems". In: Journal of Theoretical Politics 15.1, pp. 5-32.

Blaydes, Lisa (2010). Elections and distributive politics in Mubarak's Egypt. Cambridge University Press.

Boix, Carles and Milan W Svolik (2013). "The foundations of limited authoritarian government: Institutions, commitment, and power-sharing in dictatorships". In: The Journal of Politics 75.2, pp. 300-316.

Buisseret, Peter and Carlo Prato (2020). "Competing principals? Legislative representation in list proportional representation systems". In: American Journal of Political Science.

Calonico, Sebastian, Matias D Cattaneo, and Rocio Titiunik (2014). "Robust data-driven inference in the regression-discontinuity design". In: The Stata Journal 14.4, pp. 909946.

Calvo, Ernesto and Timothy Hellwig (2011). "Centripetal and centrifugal incentives under different electoral systems". In: American Journal of Political Science 55.1, pp. 27-41.

Carey, John M and Matthew Soberg Shugart (1995). "Incentives to cultivate a personal vote: A rank ordering of electoral formulas". In: Electoral studies 14.4, pp. 417-439.

Chang, Eric CC and Miriam A Golden (2007). "Electoral systems, district magnitude and corruption". In: British journal of political science, pp. 115-137. 
Chubb, Judith (1982). Patronage, power and poverty in southern Italy: a tale of two cities. Cambridge University Press.

Coppedge, Michael, John Gerring, Carl Henrik Knutsen, Staffan I Lindberg, Jan Teorell, David Altman, Michael Bernhard, M Steven Fish, Adam Glynn, Allen Hicken, et al. (2020). "V-Dem Dataset V10". In:

Cox, Gary W (1990). "Centripetal and centrifugal incentives in electoral systems". In: American Journal of Political Science, pp. 903-935.

Crisp, Brian F and Scott W Desposato (2004). "Constituency building in multimember districts: collusion or conflict?" In: The Journal of Politics 66.1, pp. 136-156.

Desposato, Scott W (2006). "The impact of electoral rules on legislative parties: Lessons from the Brazilian Senate and Chamber of Deputies". In: The Journal of Politics 68.4, pp. $1018-1030$.

Diaz-Cayeros, Alberto and Beatriz Magaloni (2001). "Party dominance and the logic of electoral design in Mexico's transition to democracy". In: Journal of Theoretical Politics 13.3, pp. 271-293.

Distelhorst, Greg and Yue Hou (2017). "Constituency service under nondemocratic rule: Evidence from China". In: The Journal of Politics 79.3, pp. 1024-1040.

Enikolopov, Ruben, Vasily Korovkin, Maria Petrova, Konstantin Sonin, and Alexei Zakharov (2013). "Field experiment estimate of electoral fraud in Russian parliamentary elections". In: Proceedings of the National Academy of Sciences 110.2, pp. 448-452.

Fearon, James D (1999). "Electoral accountability and the control of politicians: selecting good types versus sanctioning poor performance". In: Manin, B. and Przeworski, A. and Stokes, S. (ed) Democracy, accountability, and representation 2, p. 61.

Fenno, Richard F (1978). Home style: House members in their districts. HarperCollins, 
Frye, Timothy (2017). Property Rights and Property Wrongs: How Power, Institutions, and Norms Shape Economic Conflict in Russia. Cambridge University Press.

Frye, Timothy, Ora John Reuter, and David Szakonyi (2018). "Hitting them with carrots: Voter intimidation and vote buying in Russia". In: British Journal of Political Science 49.3, pp. $857-881$.

- (2014). "Political Machines at Work Voter Mobilization and electoral subversion in the Workplace". In: World Politics 66.2, pp. 195-228.

- (2019). "Vote brokers, clientelist appeals, and voter turnout: Evidence from Russia and Venezuela". In: World Politics 71.4, pp. 710-746.

Gagliarducci, Stefano, Tommaso Nannicini, and Paolo Naticchioni (2011). "Electoral rules and politicians' behavior: a micro test". In: American Economic Journal: Economic Policy 3.3, pp. 144-74.

Gandhi, Jennifer (2008). Political institutions under dictatorship. Cambridge University Press.

Gandhi, Jennifer and Abigail L Heller (2018). "Electoral systems in authoritarian states". In: The Oxford Handbook of Electoral Systems, p. 387.

Gandhi, Jennifer and Ellen Lust-Okar (2009). "Elections under authoritarianism". In: Annual review of political science 12, pp. 403-422.

Gandhi, Jennifer and Adam Przeworski (2007). "Authoritarian institutions and the survival of autocrats". In: Comparative political studies 40.11, pp. 1279-1301.

Gandhi, Jennifer, Abigail L. Heller, and Ora John Reuter (2019). "Shoring up Power: Electoral Reform and the Consolidation of Authoritarian Rule". In: Working paper, pp. 1-39. 
Golosov, Grigorii V (2017). “Authoritarian Learning in the Development of Russia's Electoral System". In: Russian Politics 2.2, pp. 182-205.

Hale, Henry E (2007). "Correlates of clientelism: political economy, politicized ethnicity, and post-communist transition". In: Patrons, Clients, and Policies: Patterns of Democratic Accountability and Political Competition, pp. 227-250.

- (1999). "Machine politics and institutionalized electorates: A comparative analysis of six Duma elections in Bashkortostan". In: The Journal of Communist Studies and Transition Politics 15.4, pp. 70-110.

- (2005). "The Market Model and Theories of Parties, National Integration, and Transitions from Authoritarian Rule". In: Why Not Parties in Russia?: Democracy, Federalism, and the State. Cambridge University Press, 1-248.

Hale, Henry E and Robert Orttung (2003). "The Duma Districts - Key to Putin's Power". In: PONARS Policy Memo 290, pp. 1-10.

Haspel, Moshe, Thomas F Remington, and Steven S Smith (1998). "Electoral institutions and party cohesion in the Russian Duma". In: The Journal of Politics 60.2, pp. 417439.

Higashijima, Masaaki and Eric CC Chang (2016). "The choice of electoral systems in dictatorships". In: Manuscript, Version 5.

Krol, Gerrit (2017). "Legislative performance of the Russian State Duma: the role of parliament in an authoritarian regime". In: East European Politics 33.4, pp. 450-471. Kunicova, Jana and Thomas Frederick Remington (2008). "Mandates, Parties and Dissent: Effect of Electoral Rules on Parliamentary Party Cohesion in the Russian State Duma, 1994-2003". In: Party Politics 14.5, pp. 555-574. 
Levitsky, Steven and Lucan Way (2002). "The rise of competitive authoritarianism". In: Journal of democracy 13.2, pp. 51-65.

Lust-Okar, Ellen (2004). "Divided they rule: The management and manipulation of political opposition". In: Comparative Politics, pp. 159-179.

- (2006). "Elections under authoritarianism: Preliminary lessons from Jordan". In: Democratization 13.3, pp. 456-471.

Lust-Okar, Ellen and Amaney Ahmad Jamal (2002). "Rulers and rules: reassessing the influence of regime type on electoral law formation". In: Comparative Political Studies 35.3, pp. 337-366.

Magaloni, Beatriz (2008). "Credible power-sharing and the longevity of authoritarian rule". In: Comparative Political Studies 41.4-5, pp. 715-741.

Malesky, Edmund and Paul Schuler (2010). "Nodding or needling: Analyzing delegate responsiveness in an authoritarian parliament". In: American Political Science Review 104.3, pp. 482-502.

- (2011). "The Single-Party Dictator's Dilemma: Information in Elections without Opposition". In: Legislative Studies Quarterly 36.4, pp. 491-530.

Milesi-Ferretti, Gian Maria, Roberto Perotti, and Massimo Rostagno (2002). "Electoral systems and public spending". In: The Quarterly Journal of Economics 117.2, pp. 609657.

Moraski, Bryon (2007). "Electoral system reform in democracy's grey zone: Lessons from Putin's Russia". In: Government and Opposition 42.4, pp. 536-563.

Motolinia, Lucia (2020). "Electoral Accountability and Particularistic Legislation: Evidence from an Electoral Reform in Mexico". In: American Political Science Review, pp. 1-46. 
Myerson, Roger B (1993). "Incentives to cultivate favored minorities under alternative electoral systems". In: American Political Science Review, pp. 856-869.

Noble, Ben (2017). "Amending budget bills in the Russian State Duma". In: PostCommunist Economies 29.4, pp. 505-522.

Noble, Ben and Ekaterina Schulman (2018). Not Just a Rubber Stamp Parliament and Lawmaking in Triesman, D (ed): The New Autocracy: Information, Politics, and Policy in Putin's Russia. Brookings Institution Press.

Persson, Torsten, Gerard Roland, Guido Tabellini, et al. (2007). "Electoral rules and government spending in parliamentary democracies". In: Quarterly Journal of Political Science 2.2, pp. $155-188$.

Remington, Thomas F (2008a). "Patronage and the party of power: President-Parliament relations under Vladimir Putin”. In: Europe-Asia Studies 60.6, pp. 959-987.

- (2014). Presidential decrees in Russia: A comparative perspective. Cambridge University Press.

- (2006). "Presidential Support in the Russian State Duma". In: Legislative Studies Quarterly 31.1, pp. 5-32. ISSN: 03629805. URL: http://www.jstor.org/stable/40263372.

- (2007). "The Russian Federal Assembly, 1994-2004". In: The Journal of Legislative Studies 13.1, pp. 121-141.

- (2008b). The Russian parliament: Institutional evolution in a transitional regime, 19891999. Yale University Press.

Remington, Thomas F and Steven S Smith (1996). "Political goals, institutional context, and the choice of an electoral system: the Russian parliamentary election law". In: American Journal of Political Science, pp. 1253-1279. 
Reuter, Ora John (2013). "Regional patrons and hegemonic party electoral performance in Russia". In: Post-Soviet Affairs 29.2, pp. 101-135.

Reuter, Ora John and Graeme B Robertson (2012). "Subnational appointments in authoritarian regimes: Evidence from Russian gubernatorial appointments". In: The Journal of Politics 74.4, pp. 1023-1037.

Sieberer, Ulrich (2010). "Behavioral consequences of mixed electoral systems: Deviating voting behavior of district and list MPs in the German Bundestag". In: Electoral Studies 29.3, pp. 484-496.

Svolik, Milan W (2013). "Contracting on violence: The moral hazard in authoritarian repression and military intervention in politics". In: Journal of Conflict Resolution 57.5, pp. $765-794$.

- (2012). The politics of authoritarian rule. Cambridge University Press.

Szakonyi, David (2018). "Businesspeople in elected office: Identifying private benefits from firm-level returns". In: American Political Science Review 112.2, pp. 322-338.

The Washington Post (1999). "Immunity Rule Draws Russians To Politics - Duma Seats Protect Accused Criminals". In: Hoffman, David November 14, 1999; Page A22e.

Truex, Rory (2016). Making autocracy work: representation and responsiveness in modern China. Cambridge University Press.

White, Stephen and Ol'ga Kryshtanovskaya (2011). "Changing the Russian electoral system: Inside the black box". In: Europe-Asia Studies 63.4, pp. 557-578. 


\section{Appendix}

Electoral Systems and the Autocrat's Trade-Off: Evidence From The Russian Duma 


\section{A Descriptive illustrations}

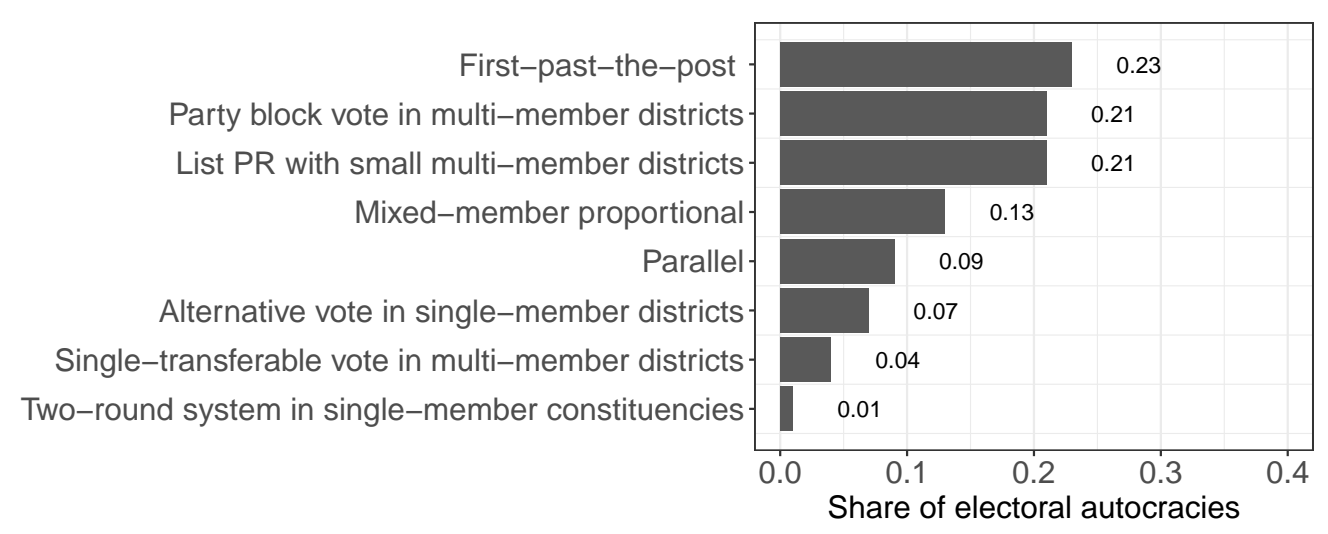

Figure A.1: Distribution of electoral system (lower chamber) for most recent election in current autocracies. Data from Varieties of Democracy dataset (id "v2elloelsy").

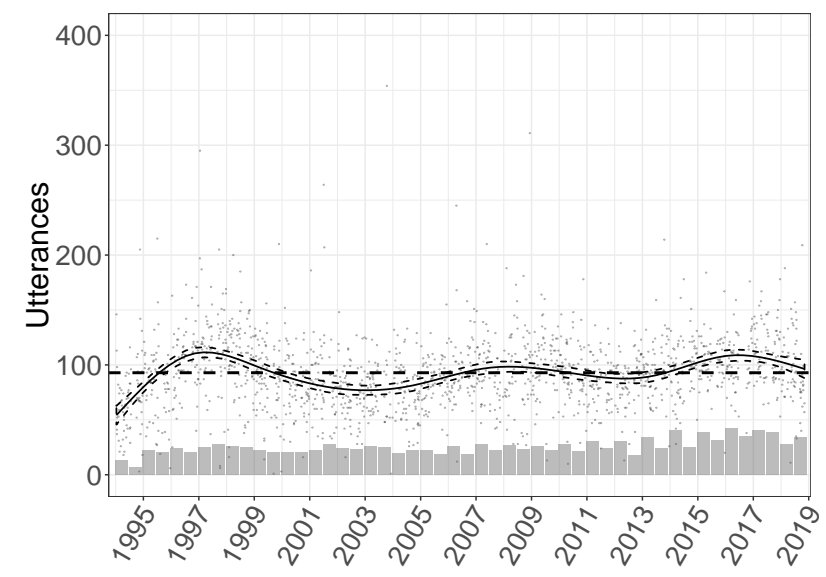

Figure A.2: Speech Activity Across Period of Investigation

Figure A.2 shows a stable speech activity over time. On average, there are 91 unique deputy-topic utterances, and approximately 25 points on the agenda. 


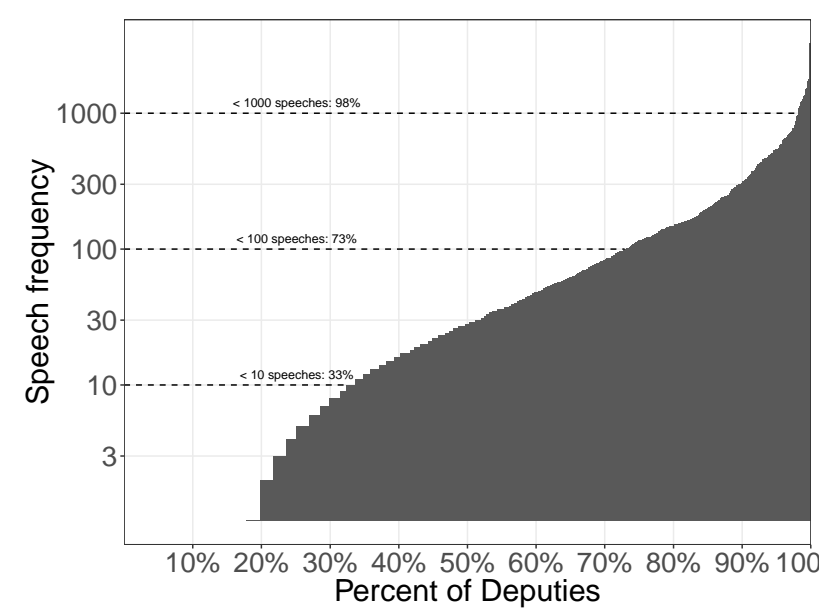

Figure A.3: Speech Activity Across Period of Investigation

Figure A.3 adds to Figure A.2 in showing that it is not simply a few, very active deputies who keep the general activity high in the Russian Duma. Thus, many deputies access the floor of the Duma at one point throughout the parliamentary session. Whereas thirty-three percent have spoken fewer than 10 times, twenty-seven percent have spoken more than one-hundred times.

\section{B Design considerations}

Table A.1 shows difference-in-means between dual included deputies and regular candidates. Whereas only minor differences - none of which are significant - exist between the types of deputies on gender, age, being elected on the federal aspect of the PR list as well as district size, seniority, and rank on the PR list, statistically significant differences exist for being elected in Moscow or Sct Petersburg (Urban). Interestingly, from the (not statistically significant) difference in party rank, dual included deputies appear to be more prominent politicians. Identifying an effect for dual included candidates is therefore noteworthy in itself, as the Russian regime is particularly concerned with the behavior or parliamentary elites. 
Table A.1: Differences Between Dual Included Deputies and Regular Deputies

\begin{tabular}{lccccccc}
\hline & Woman & Age & Seniority & Federal (PR) & District Size & Urban & Rank (PR) \\
& $(1)$ & $(2)$ & $(3)$ & $(4)$ & $(5)$ & $(6)$ & $(7)$ \\
\hline Dual Included & 0.011 & 3.229 & -1.319 & -0.011 & 1.214 & $0.165^{* * *}$ & 4.919 \\
& $(0.031)$ & $(4.020)$ & $(1.376)$ & $(0.011)$ & $(4.358)$ & $(0.018)$ & $(5.916)$ \\
$\mathrm{N}$ & 2,799 & 2,264 & 942 & 2,799 & 1,162 & 2,799 & 1,764 \\
\hline Notes: $* \mathrm{p}<.1 ; * * \mathrm{p}<.05 ; * * * \mathrm{p}<.01$. & All models are differences-in-means between dual \\
included and non-dual included deputies.
\end{tabular}

Table A.2: The proportion and electoral success of candidates across categories

\begin{tabular}{ccccccc}
\hline \hline Convocation & No. candidates & Pct. elected & Dual candidates & $\begin{array}{c}\text { Dual candidates } \\
\text { elected }\end{array}$ & $\begin{array}{c}\text { District } \\
\text { deputy }\end{array}$ & $\begin{array}{c}\text { Federal } \\
\text { deputy }\end{array}$ \\
\hline 7 & 6,172 & 7.3 & $1469(23.8 \%)$ & $78(5.3 \%)$ & $25(32.1 \%)$ & $53(67.9 \%)$ \\
4 & 4,949 & 9.1 & $627(12.7 \%)$ & $108(17.2 \%)$ & $68(63 \%)$ & $40(37 \%)$ \\
3 & 5,704 & 7.9 & $673(11.8 \%)$ & $113(16.8 \%)$ & $66(58.4 \%)$ & $47(41.6 \%)$ \\
2 & 7,768 & 5.8 & $740(9.5 \%)$ & $104(14.1 \%)$ & $63(60.6 \%)$ & $41(39.4 \%)$ \\
1 & 501 (incomplete) & 89.8 & $159(31.7 \%)$ & $112(70.4 \%)$ & $59(52.7 \%)$ & $53(47.3 \%)$ \\
\hline
\end{tabular}

Note First convocation is incomplete in that not all deputies were collected. However, all dual candidates are included in the sample.

\section{B.1 Sorting}

The intuition in the design mimics a close-election regression-discontinuity design, where the random component of an electoral result makes up the chance process. Whether such random component is in fact random in a non-democratic regime is a non-trivial issue. One concern is that candidates affiliated with the regime can make use of fraudulent behavior to reach $M V_{i}>0$, if the election is deemed a close-call. Such sorting strategy frees up a federal list seat in addition to the single-member district seat. Consequently, the party gains an extra deputy. Figure A.4 addresses the issue of sorting around the margin of victory threshold of zero, by plotting the distribution of margin of victories. As can be seen, there is a jump in close proximity to the threshold, such that more candidates barely win than lose a district. This jump is not obviously caused by United Russia candidates being pushed over the line (see Table 1 in the text) and could partly be mechanical: while 
it is enough for a deputy to win the district to be elected to parliament, deputies losing the district will additionally require a sufficient rank to be elected. To address the density issue, we 1) introduce party fixed effects 2) run a "donut" type specification, excluding deputies with margin of victories within $+/-0.05$ of the threshold.

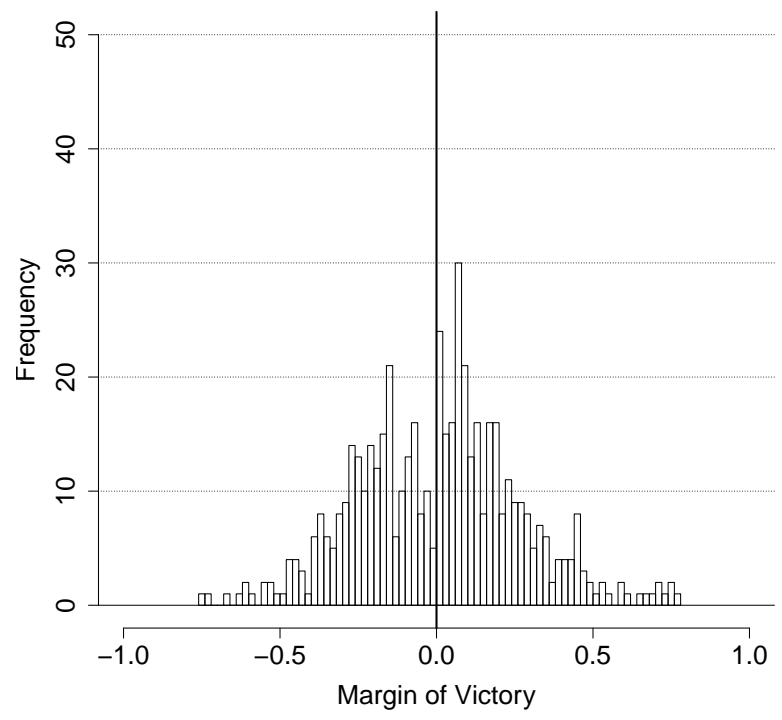

Figure A.4: Sorting Around Threshold

Note: Bins each make up two pct. point. Solid line indicates cutoff value.

To address sorting, the Table A.3 runs equation 1 with 1) party fixed effects 2) excluding observations close to the threshold, specifically observations for which $\operatorname{abs}(M V)<$ 0.05. Results are overall unchanged, though party fixed effects do make the estimates less efficient, particularly in row two. This is unsurprising. With the large turnover of parties from the beginning of the 1990s to the early 2000s, this introduces many more levels of fixed effects (27 in total) compared to convocation fixed effects ( 7 in total). 
Table A.3: Robustness: Party Fixed Effects and Donut RDD

\begin{tabular}{|c|c|c|c|}
\hline \multirow[b]{2}{*}{ Bandwidth } & \multicolumn{3}{|c|}{ Local Amendments: fe } \\
\hline & 0.35 & 0.25 & 0.15 \\
\hline$S M D$ & $\begin{array}{c}0.27^{* *} \\
(0.12)\end{array}$ & $\begin{array}{c}0.13 \\
(0.13)\end{array}$ & $\begin{array}{c}0.11 \\
(0.18)\end{array}$ \\
\hline \multirow[t]{2}{*}{$\mathrm{N}$} & 917 & 746 & 498 \\
\hline & \multicolumn{3}{|c|}{ Law Obstruction: Party fe } \\
\hline$S M D$ & $\begin{array}{c}0.04 \\
(0.04)\end{array}$ & $\begin{array}{c}0.04 \\
(0.05)\end{array}$ & $\begin{array}{c}0.09 \\
(0.07)\end{array}$ \\
\hline \multirow[t]{2}{*}{$\mathrm{N}$} & 875 & 718 & 478 \\
\hline & \multicolumn{3}{|c|}{ Local Amendments: Excl. abs $(\mathrm{MV})<.05$} \\
\hline$S M D$ & $\begin{array}{c}0.36^{* * *} \\
(0.13)\end{array}$ & $\begin{array}{l}0.23^{*} \\
(0.14)\end{array}$ & $\begin{array}{c}0.17 \\
(0.18)\end{array}$ \\
\hline \multirow[t]{2}{*}{$\underline{\mathrm{N}}$} & 917 & 746 & 498 \\
\hline & \multicolumn{3}{|c|}{ Law Obstruction: Excl. abs $(\mathrm{MV})<.05$} \\
\hline$S M D$ & $\begin{array}{l}0.09^{*} \\
(0.05)\end{array}$ & $\begin{array}{c}0.13^{* *} \\
(0.06)\end{array}$ & $\begin{array}{c}0.18 \\
(0.11)\end{array}$ \\
\hline $\mathrm{N}$ & 698 & 541 & 301 \\
\hline
\end{tabular}

Notes: ${ }^{*} \mathrm{p}<.1 ;{ }^{* *} \mathrm{p}<.05 ;{ }^{* * *} \mathrm{p}<.01$. Models are of the form $y=S M D+M V+S M D * M V$, but only the first term is reported. Models control for age and gender. Dependent variable is the ration of absence to votes across the whole convocation. Std.errors clustered at the deputy-convocation level (i.e. level of treatment assignment). 


\section{Analysis}

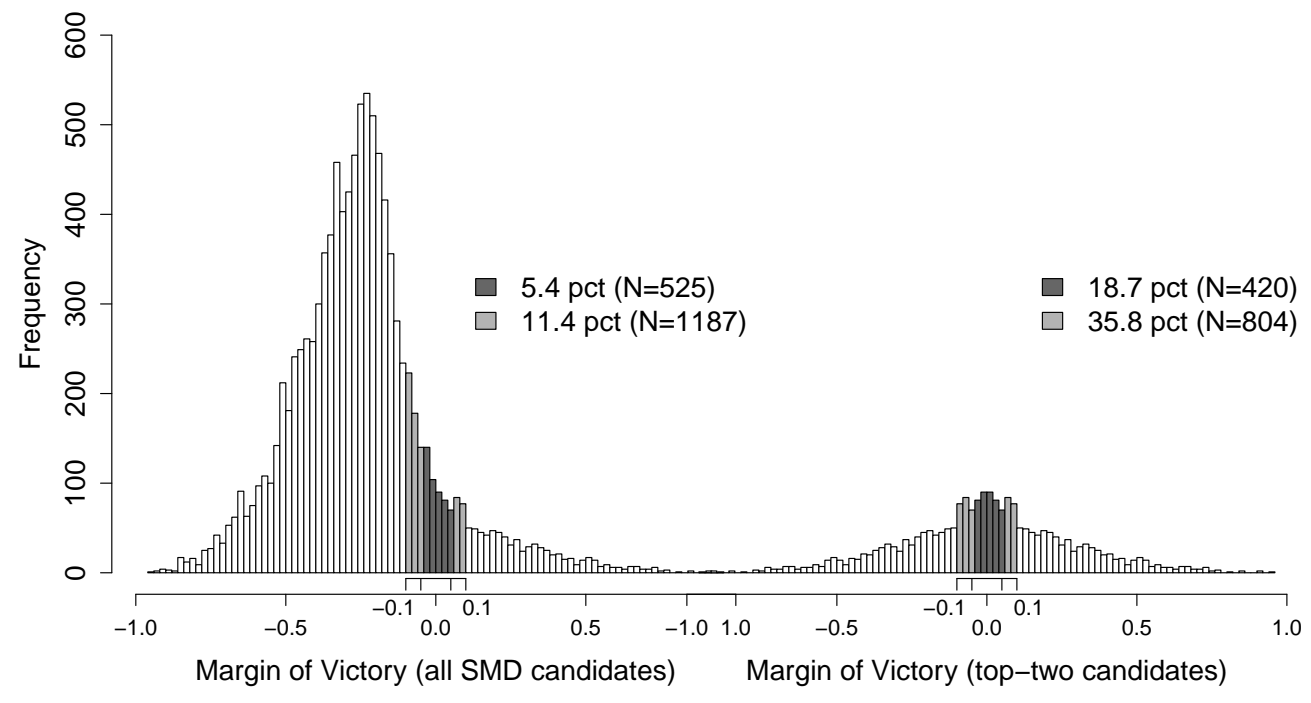

Figure A.5: Competition Across Single-Member Districts

The regression-discontinuity estimator approximates the effect of list affiliation for margins of victory close zero, i.e. for close call district races. One may therefore question the prospects of inference, if competitive districts are very uncommon in Russia. However, Figure A.5 suggests they are not. Whereas the left panel is per construction skewed (unless only two candidates compete in a district race, more candidates will lose than win), they right panel indicates that races are normally distributed with mean close zero. The right panel shows that thirty-six percent of district races are within an absolute margin of victory of 0.1 , and just short of twenty percent are within 0.05 . To conclude, nothing indicates that deputies elected in competitive districts are idiosyncratic.. Data includes all candidates registered in a district, who ran in 1993, 1995, 1999, 2003 and 2016 included.

Table A.4 runs equation 1 on measures of general effort exerted by deputies: general speech activity and total flights taken. Interestingly, whereas list affiliation affects effort directly benefiting local constituencies, including suggesting local amendments and traveling to the home region, there is no effect on speech activity generally, nor total flights taken. This plausibly suggests that also federal list deputies face incentives to exert effort for their constituencies, though such constituencies differ in type. 
Table A.4: General Effort

\begin{tabular}{|c|c|c|c|c|c|c|}
\hline \multirow[b]{2}{*}{ Bandwidth } & \multicolumn{6}{|c|}{ Speech Effort (dual included deputies) } \\
\hline & 1 & 0.65 & 0.5 & 0.35 & 0.2 & 0.05 \\
\hline$S M D$ & $\begin{array}{c}8.43 \\
(11.54)\end{array}$ & $\begin{array}{c}5.74 \\
(12.32)\end{array}$ & $\begin{array}{c}3.34 \\
(13.56)\end{array}$ & $\begin{array}{l}-12.52 \\
(14.45)\end{array}$ & $\begin{array}{c}-9.88 \\
(17.74)\end{array}$ & $\begin{array}{c}25.85 \\
(25.95)\end{array}$ \\
\hline \multirow[t]{2}{*}{$\mathrm{N}$} & 514 & 502 & 486 & 427 & 290 & 66 \\
\hline & \multicolumn{6}{|c|}{ Speech Effort (dual included and all district deputies } \\
\hline$S M D$ & $\begin{array}{c}-1.65 \\
(10.43)\end{array}$ & $\begin{array}{c}-3.91 \\
(11.10)\end{array}$ & $\begin{array}{c}-6.78 \\
(12.16)\end{array}$ & $\begin{array}{c}-20.29 \\
(12.68)\end{array}$ & $\begin{array}{c}-20.23 \\
(16.10)\end{array}$ & $\begin{array}{c}-4.44 \\
(22.49)\end{array}$ \\
\hline \multirow[t]{2}{*}{$\mathrm{N}$} & 1,167 & 1,133 & 1,074 & 934 & 645 & 185 \\
\hline & \multicolumn{6}{|c|}{ Total Flights (dual included deputies) } \\
\hline$S M D$ & $\begin{array}{c}-5.83 \\
(15.54)\end{array}$ & $\begin{array}{c}-7.19 \\
(16.75)\end{array}$ & $\begin{array}{c}-7.23 \\
(18.77)\end{array}$ & $\begin{array}{c}-4.71 \\
(21.27)\end{array}$ & $\begin{array}{c}-9.12 \\
(22.85)\end{array}$ & $\begin{array}{c}30.70 \\
(60.44)\end{array}$ \\
\hline \multirow[t]{2}{*}{$\mathrm{N}$} & 113 & 105 & 97 & 81 & 48 & 15 \\
\hline & \multicolumn{6}{|c|}{ Total Flights (dual included and all district deputies } \\
\hline$S M D$ & $\begin{array}{c}-8.63 \\
(11.33)\end{array}$ & $\begin{array}{c}-10.26 \\
(11.96)\end{array}$ & $\begin{array}{c}-6.13 \\
(13.78)\end{array}$ & $\begin{array}{c}-1.25 \\
(15.26)\end{array}$ & $\begin{array}{c}-13.11 \\
(18.82)\end{array}$ & $\begin{array}{c}30.66 \\
(42.89)\end{array}$ \\
\hline $\mathrm{N}$ & 247 & 228 & 204 & 167 & 104 & 34 \\
\hline
\end{tabular}

Notes: ${ }^{*} \mathrm{p}<.1 ; * * \mathrm{p}<.05 ; * * * \mathrm{p}<.01$. Models in column

2:7 of the form $y=S M D+M V+S M D * M V$, but only

the first term is reported. Models control for age and

gender. Column 1 is the difference in means for $b w=1$.

Dependent variable is the number of speeches across the

whole convocation. Std.errors clustered at the deputy-

convocation level (i.e. level of treatment assignment).

Table A.5 contains the data behind Figure 4. Particularly worth noticing is the effect sizes on local amendments, which seems is substantially reduced compared to effect sizes in the whole period (see Table 3). Also worth noticing is the smaller sample sizes, which plausibly explains the statistically insignificant results. See Figure 4 in the text for an elaborate interpretation. 
Table A.5: Trade-Off After Re-Introduction of Mixed-Member System

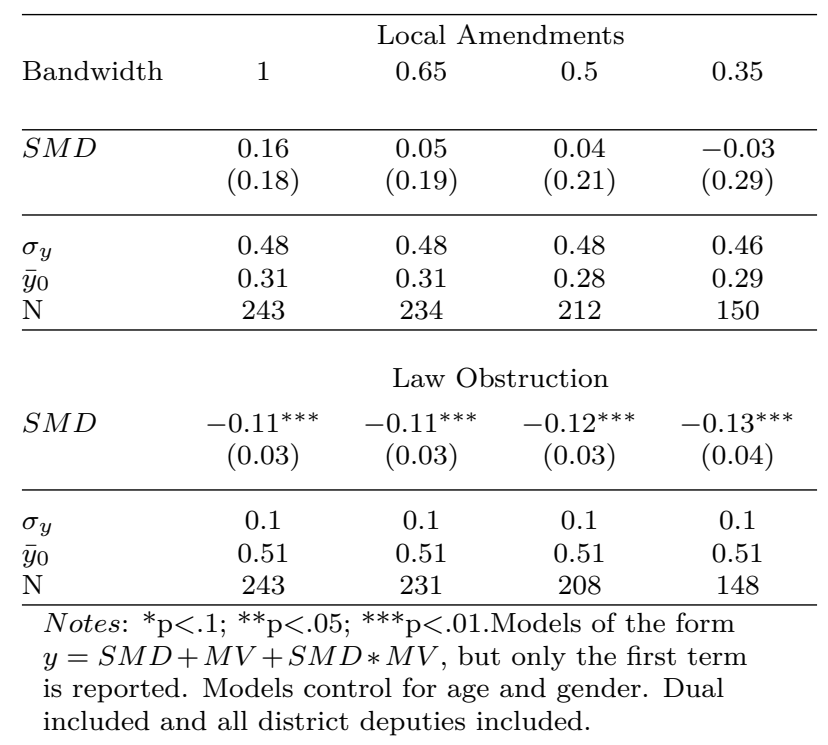

Table A.6: The Effect Across Periods

\begin{tabular}{|c|c|c|c|}
\hline \multirow[b]{2}{*}{ Period } & \multicolumn{3}{|c|}{ Local Amendments } \\
\hline & 1993-1999 & $1999-2007$ & $2016-2020$ \\
\hline$S M D$ & $\begin{array}{c}0.55^{* * *} \\
(0.18)\end{array}$ & $\begin{array}{l}-0.06 \\
(0.08)\end{array}$ & $\begin{array}{c}0.16 \\
(0.18)\end{array}$ \\
\hline \multirow[t]{2}{*}{$\mathrm{N}$} & 422 & 456 & 243 \\
\hline & \multicolumn{3}{|c|}{ Law Obstruction } \\
\hline$S M D$ & $\begin{array}{c}0.17^{* *} \\
(0.07)\end{array}$ & $\begin{array}{c}-0.004 \\
(0.02)\end{array}$ & $\begin{array}{c}-0.11^{* * *} \\
(0.03)\end{array}$ \\
\hline $\mathrm{N}$ & 414 & 438 & 243 \\
\hline \multicolumn{4}{|c|}{$\begin{array}{l}\text { Notes: }{ }^{*} \mathrm{p}<.1 ;{ }^{*} \mathrm{p}<.05 ; * * * \mathrm{p}<.01 . \\
\text { Models are of the form } y=S M D+ \\
M V+S M D * M V, \text { but only the first } \\
\text { term is reported. Models control for } \\
\text { age and gender. Dual included and } \\
\text { all district deputies included. }\end{array}$} \\
\hline
\end{tabular}

\section{Random Forest Classification of Local Amendments}

Below analysis re-runs Table 3, Table A.3, Table Table A.10 and Figure 4, but replaces the dictionary measure with a random forest classification. First, the classification is describes and subsequently the analysis is presented. All results are consistent, both in terms of statistical significance and effect sizes.

Local constituency representation is conceptualized along two dimensions. The distributive dimension is understood broadly as favorable economic regulations or invest- 
ments. The local dimension stresses that deputies have to explicitly mention a particular area (e.g. city, region). Though it is not a coding requirement that the deputy is in fact referring to her own constituency, close reading indicates that this is most often the case. Examples include demands for investments following severe de-industrialization in the North Caucasus and flagging consequences of a pension reform for regional equalization in payouts in the Ural mountains region. ${ }^{19}$

\section{D.1 Classifying Suggested Amendments}

We trained random forest model on a subset of 4.000 speeches hand coded in their original language by a student assistant. For this subset, a dummy indicates whether the text conveys a local distributive interest (1) or not (0). The remaining documents were then classified using the trained model. Following standard procedures, the documents were stemmed and stop words as well as numbers were excluded. Speeches have an average length of 250 words. Classifier performance is visible in Table A.7.

Table A.7: Classifier Performance

\begin{tabular}{|lcc|}
\hline & True Negative & True Positive \\
Predicted Negative & 3533 & 292 \\
Predicted Positive & 56 & 119 \\
\hline \hline Accuracy $=0.95$ & Balanced Accuracy $=0.64$ & \\
True negative rate $=0.98$ & True positive rate $=0.29$ & \\
\hline
\end{tabular}

The model is evaluated using out-of-bag error. The model is conservative in classifying texts: conditioned on correct classification of almost all true negatives, it correctly predicts a third of all true positives, with an overall accuracy of 95 percent, and a balanced accuracy of 64 percent. It is worth noting that in the handcoding, a local distributive

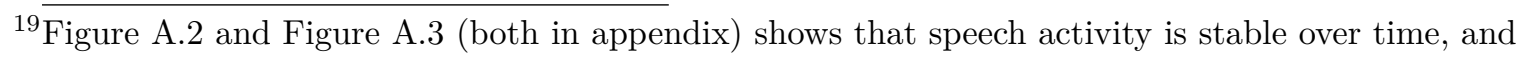
spread across deputies.
} 
interest is present in ten percent of the 4,000 randomly sampled documents. Though not accounting for everything that is going on in the Duma, this observation does indicate that a substantial part of speech-activity is dedicated to flagging local interests. ${ }^{20}$

Simple face validity checks suggests that the model is able to capture central aspects of the concept. First, the correlation between references to the home region (the central measure of local amendments) and the random forest classification (Table A.8) suggests that texts classified as local distributive following the random forest model, contain references to locations in the home region $.39^{* * *}$ times more often. In turn, for each time the dictionary method mentions a home region location, the likelihood that the random forest model classifies a text as local distributive increases with $2.4 \%$.

Table A.8: Association between dictionary estimate and random forest estimate

\begin{tabular}{lcc}
\hline & $\begin{array}{c}\text { Dictionary estimate } \\
(1)\end{array}$ & Random forest estimate \\
& $0.385^{* * *}$ & $(2)$ \\
Random forest estimate & $(0.016)$ & $0.024^{* * *}$ \\
Dictionary estimate & $(0.001)$ \\
$\mathrm{N}$ & 58,447 & 58,447 \\
\hline Notes: ${ }^{*} \mathrm{p}<.1 ; * * \mathrm{p}<.05 ;{ }^{* * *} \mathrm{p}<.01$. Estimations run at the speech \\
level for dual included and district candidates. Dictionary estimate \\
is an integer measure with mean 0.267. Random forest estimate is a \\
binary measure with mean 0.046.
\end{tabular}

Second, the Duma chairman scores much lower on the measure than do both party list and district deputies. This is to be expected, as most of the chairman's utterances concern procedural aspects. It is thus comforting that the chairman speaks about local distributive preferences only 0.36 percent of the time, with federal list deputies speaking of local issues 11 times as often (mean $4.0^{*}$ percent) and district deputies 14 times as

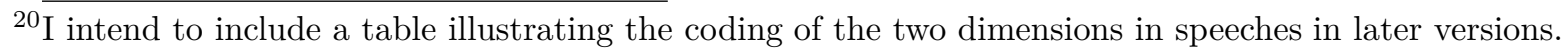


often (mean $4.9^{* * *}$ percent). Finally, cabinet members - with no direct constituency has a mean of 1 percent, with elected deputies mentioning local interests $3.4^{* * *}$ percent of the time. Though neither observation proves the model, the opposite result would be a cause for concern.

Table A.9: Local Amendments: Party Fixed Effects and Donut RDD (Robustness): Random Forest Classification

\begin{tabular}{|c|c|c|c|c|c|}
\hline \multirow[b]{2}{*}{ Bandwidth } & \multicolumn{5}{|c|}{ Local Amendments: Party Fixed Effects } \\
\hline & 1 & 0.75 & 0.5 & 0.35 & 0.15 \\
\hline$S M D$ & $\begin{array}{c}0.03^{* * *} \\
(0.01)\end{array}$ & $\begin{array}{c}0.02^{* * *} \\
(0.01)\end{array}$ & $\begin{array}{c}0.02^{* *} \\
(0.01)\end{array}$ & $\begin{array}{c}0.03^{* * *} \\
(0.01)\end{array}$ & $\begin{array}{c}0.03^{* *} \\
(0.02)\end{array}$ \\
\hline \multirow[t]{2}{*}{$\mathrm{N}$} & 1,167 & 1,160 & 1,074 & 934 & 507 \\
\hline & \multicolumn{5}{|c|}{ Law Obstruction: Party Fixed Effects } \\
\hline$S M D$ & $\begin{array}{c}0.06^{*} \\
(0.03) \\
1,095\end{array}$ & $\begin{array}{c}0.05^{*} \\
(0.03) \\
1,088\end{array}$ & $\begin{array}{c}0.06^{*} \\
(0.03) \\
1,007\end{array}$ & $\begin{array}{c}0.04 \\
(0.04) \\
875\end{array}$ & $\begin{array}{c}0.09 \\
(0.07) \\
478\end{array}$ \\
\hline $\mathrm{N}$ & \multicolumn{5}{|c|}{ Local Amendments: Excluding abs(MV) $<0.05$} \\
\hline$S M D$ & $\begin{array}{c}0.03^{* * *} \\
(0.01)\end{array}$ & $\begin{array}{c}0.03^{* * *} \\
(0.01)\end{array}$ & $\begin{array}{c}0.03^{* * *} \\
(0.01)\end{array}$ & $\begin{array}{c}0.04^{* * *} \\
(0.01)\end{array}$ & $\begin{array}{c}0.04^{* * *} \\
(0.02)\end{array}$ \\
\hline \multirow[t]{2}{*}{$\mathrm{N}$} & 1,167 & 1,160 & 1,074 & 934 & 507 \\
\hline & \multicolumn{2}{|c|}{ Law Obstruction } & Excludi & $\mathrm{g} \operatorname{abs}(\mathrm{M}$ & $<0.05$ \\
\hline$S M D$ & $\begin{array}{c}0.07^{* *} \\
(0.03)\end{array}$ & $\begin{array}{c}0.07^{* *} \\
(0.03)\end{array}$ & $\begin{array}{c}0.09^{* *} \\
(0.04)\end{array}$ & $\begin{array}{l}0.09^{*} \\
(0.05)\end{array}$ & $\begin{array}{c}0.18 \\
(0.11)\end{array}$ \\
\hline $\mathrm{N}$ & 918 & 911 & 830 & 698 & 301 \\
\hline \multicolumn{6}{|c|}{$\begin{array}{l}\text { Notes: }{ }^{*} \mathrm{p}<.1 ; * * \mathrm{p}<.05 ;{ }^{* * *} \mathrm{p}<.01 . \text { Models are } \\
\text { of the form } y=S M D+M V+S M D * M V \text {, } \\
\text { but only the first term is reported. Models } \\
\text { control for age and gender. Dependent variable } \\
\text { is the ration of absence to votes across the } \\
\text { whole convocation. Std.errors clustered at the } \\
\text { deputy-convocation level (i.e. level of treatment } \\
\text { assignment). }\end{array}$} \\
\hline
\end{tabular}

Table A.10: The Effect Across Periods (Robustness): Random Forest Classification

\begin{tabular}{lccc}
\hline \multicolumn{4}{c}{ Local Amendments } \\
Period & $1993-1999$ & $1999-2007$ & $2016-2020$ \\
\hline$S M D$ & $0.05^{* * *}$ & 0.01 & 0.02 \\
& $(0.02)$ & $(0.01)$ & $(0.05)$ \\
$\mathrm{N}$ & 447 & 469 & 251 \\
\hline \multicolumn{4}{c}{ Law Obstruction } \\
SMD & $0.17^{* *}$ & -0.004 & $-0.11^{* * *}$ \\
$\mathrm{~N}$ & $(0.07)$ & $(0.02)$ & $(0.03)$ \\
$\mathrm{N}$ & 414 & 438 & 243 \\
\hline Notes: *p $<.1 ; * * \mathrm{p}<.05 ; * * * \mathrm{p}<.01$. \\
Models are of the form $y=S M D+$ \\
$M V+S M D * M V$, but only the first \\
term is reported. Models control for \\
age and gender. Dual included and \\
all district deputies included.
\end{tabular}




\section{E Intuition: electoral systems and parliamentary behavior}

The calculation is estimated for effects from the specification with optimal bandwidths in Table 3 and Table 4, i.e. column five and column four, respectively. On average, there are 7,200 speeches per year in the Russian Duma. In the estimations above, partylist deputies mention local amendments 0.25 in each speech, i.e. in every four speech. This adds up to 1,800 speeches containing local amendments a year. Deputies elected in a single-member district mention local amendments 0.42 to 0.50 times in each speech, adding up to 3,000 to 3,600 speeches over the course of one year, given the historical activity (recall Table A.4 in which list affiliation has no effect on speech activity). With respect to law obstruction, Table 4 suggests that district deputies obstruct law 12-18 percentage points more often than party-list deputies. As the mean law obstruction for party-list deputies is $43 \%-44 \%$, the the mean law obstruction for district deputies is $55 \%-62 \%$. 